\title{
Covid-19: Acquired acute porphyria?
}

Lianne Abrahams

Department of Systems Biology, Ronin Institute, 127 Haddon Place, Montclair, New Jersey, United States, 07043-2314

To whom correspondence may be addressed: lianne.abrahams@protonmail.com

Abstract

Pandemic Covid-19 pneumonia, of SARS-CoV-2 aetiology, is of global importance to health systems, national economies, and individual civil liberties. Multiple therapeutic and prophylactic agents are currently undergoing clinical trial and, while progress towards a curative agent is promising, the principal limiting factor in public health emergency is time. A pre-existing licensed therapeutic would offer reprieve to international citizens currently enduring the adverse consequences of lockdown policies. The current review advances the author's original hypothesis and advocates direct testing of the hypothesis by urinalysis of light-protected samples from critical Covid-19 patients to check for elevated aminolevulinic acid and porphobilinogen.

Keywords: SARS-Cov-2, Covid-19, Porphyria, Porphyrin, Heme Biosynthesis

\section{Introduction}

The current review advances the author's original hypothesis published as a preprint in April 2020 (1). Erythrocytes are strongly implicated in the pathophysiology of Covid-19 although their role is thought to be under-estimated. Co-efficient of variation of red blood cell distribution width (RDW) is predictive of severity of disease state (2). Elevated RDW is correlated with reduced erythrocyte turnover; red blood cells become smaller as they age and the delay in clearance expands the low-volume tail of the volume distribution (3). Suppressed erythrocyte turnover may indicate erythropoietic distress and function as a compensatory mechanism to maintain circulating red blood cell levels (3). Excess porphyrins in red blood cells can precipitate cell lysis and development of hemolytic anaemia (4). Macaques infected with SARS-CoV-2 also have decreased red blood cell numbers (5) and susceptibility to SARS-CoV-2 appears to be determined by blood group; blood group A is most affected whereas blood group 0 seems to be protected (6). This finding is concordant with previous studies showing that susceptibility to the 2003 strain of SARSCoV was determined by blood group (7). Preliminary evidence suggests that CD147, the determinant of the Ok blood group system, binds the spike protein of SARS-CoV-2 (8). Incidentally, CD147 functions as an essential receptor for erythrocyte invasion by Plasmodium falciparum (9). Blockade of CD147 abrogates the normal recirculation of erythrocytes, from the spleen into the general circulation, leading to selective trapping of red blood cells in the spleen as development of a form of anaemia (10). Autopsy of deceased Covid-19 patients reveals that the spleen may be reduced in size (11). Reduction in spleen size would be expected in the event of splenic emptying of reserve erythrocytes into the circulation as part of a normal physiological response to anaemia (12).

Primate models of Covid-19 (5) and human Covid-19 patients have subnormal hemoglobin levels (13). Clinical evaluation of almost 100 Wuhan patients reveals hemoglobin levels below the normal range in most patients as well as increased total bilirubin and elevated serum ferritin (13). Hyperbilirubinemia is observed in acute porphyria (4) and would be consistent with ineffective erythropoiesis (14) and rapid hemoglobin turnover. Elevated serum ferritin levels are typical of acute porphyria (15) and would be expected upon dissociation of iron from heme. A mechanism by which SARS-CoV-2 might disrupt the 1 beta chain of hemoglobin has been proposed; multiple SARS-Cov-2 ORF proteins are predicted to bind the porphyrin of heme and displace iron (16). If this prediction is accurate, the oxygen-carrying capacity of erythrocytes would be compromised by SARS-CoV-2, thereby exacerbating the difficulties already experienced by the patient, in terms of maintaining partial pressure of oxygen in the alveoli (PaO2).

While the impact of SARS-CoV-2 targeting of hemoglobin on oxygen content of the blood would be considerable, the author proposes that perhaps of greater concern, are potential ramifications upon homeostatic regulation of heme anabolism. Heme biosynthesis is exquisitely controlled by seven enzyme-controlled reactions proceeding from the first intermediate, aminolevulinic acid (ALA), to heme as the final product (Fig. 1). Heme negatively regulates the first step in the pathway by repressing expression of aminolevulinic acid synthase (ALAS). SARS-CoV-2 is predicted to directly interfere with heme production (16), and this prediction is consistent with empirical evidence of reduced hemoglobin levels in Covid-19 patients (13) and in animal models of the disease (5). Decreased heme production dampens repression of ALAS and may thereby increase the production of heme precursors leading to accumulation of porphyrin intermediate metabolites. All the heme pathway intermediates are potentially toxic (4). During an attack of acute porphyria, ALAS is induced (4) and this perturbation continues until sufficient heme synthesis is restored.

Phenotype of SARS-CoV-2 porphyrin excess is hypothesised to mimic extreme lead poisoning; both as examples of acquired acute porphyria. Overproduction of heme precursors - aminolevulinic acid (ALA) and porphobilinogen (PBG), in particular - manifests life-threatening attacks (21) with neurovisceral symptoms (4), including: abdominal pain (85-95\% cases), vomiting (43-88\%), constipation (48-84\%), muscle weakness (42-60\%), mental symptoms (40-58\%), pain of the limbs, head, neck and chest (50-52\%), hypertension (36-54\%), tachycardia (28-80\%), convulsion (10-20\%), sensory loss (9-38\%), fever (9-37\%), respiratory paralysis (5$12 \%)$ and diarrhoea (5-12\%). Neurotoxicity of aminolevulinic acid accounts for the plethora of neurovisceral symptoms and, interestingly, there is considerable overlap between neurovisceral complaints of ALA excess and extra-pulmonary symptoms of critical Covid-19 patients. Extra-pulmonary symptoms of Covid-19 are significant but under-estimated, including gastrointestinal symptoms (22). Neurological problems also appear to be overlooked by the hyper-focus on respiratory symptoms (23). Of 214 Covid-19 patients, 36.4\% experienced neurological manifestations including: headache, dizziness, acute cerebrovascular incidents, 
and impaired consciousness (24). Loss of autonomic control of breathing has also been reported and autonomic neuropathy is a clinical feature of acute porphyria (25). Neuropsychiatric symptoms of Covid-19 may be downstream of irregularities in heme metabolism. SARS-CoV-2 would not be the first known virus to alter porphyrin metabolism; hepatitis $C$ virus and human immunodeficiency virus infection lead to a non-acute form of porphyria (26).

In summary, the first part of the current hypothesis is that critical Covid-19 patients are experiencing a form of acquired acute porphyria (Fig. 1) and the second part is that treating critical Covid-19 patients with ALA synthase inhibitors may ameliorate extrapulmonary symptoms of the disease. Diagnosis by urinalysis of porphyrin metabolites would provide a straightforward confirmation or negation of the current hypothesis; ALA urinary excretion of $25-100 \mathrm{mg} / \mathrm{d}$ or PBG urinary excretion of 50-200 $\mathrm{mg} / \mathrm{d}$ is typical of acute porphyria (4). Current therapeutic interventions licensed for treatment of porphyria include: (i) blood transfusion (erythropoietic porphyria), (ii) glucose, (iii) intravenous haematin; and (iv) chloroquine. Chloroquine induces the release of tissue-bound porphyrins; the initial event following chloroquine administration to porphyria cutanea tarda (PCT) patients is a release of bound hepatic porphyrin and its rapid elimination (27). The remainder of the review makes eight arguments as rationale for testing the acquired acute porphyria hypothesis: (i) extracorporeal membrane oxygenation fails as a functional cure, (ii) symptomology overlap, (iii) abnormal concentrations of serum porphyrins in Covid-19, (iv) protective effect in sickle cell patients, (v) heme-binding motifs in SARS-Cov-2 proteins, (vi) spike glycoprotein induces heme oxygenase-1, (vii) impairment of heme-based oxygen sensing, (viii) nascent treatment mechanisms.

\section{ECMO fails as a functional cure}

The conventional view of SARS-Cov-2 pathology (28) is that critical disease is a viral pneumonia that progresses to acute respiratory distress syndrome (ARDS), with cytokine-storm induced hyperinflammation (29), and death by multiple organ failure. While this is largely accurate and well- evidenced, elements of the clinical manifestation of SARS-Cov- 2 infection in critical patients appear to be novel, when compared with the phenotype of critical SARS-Cov-1 patients. Perhaps the most eloquent ambassador of this opinion within the clinical medical profession is Dr. Cameron Kyle Sidell, advocate of (i) an evidence-based approach to ventilation timepoints/pressures and (ii) re-questioning the Covid-19 phenotype (30). If the conventional view of Covid-19 as a viral pneumonia - in which ARDS drives hypoxia - is sufficiently accurate, ECMO would be expected to closely represent a functional cure. ECMO bypasses the requirement of the lungs to be functional, by directly oxygenating and circulating blood mechanically, therefore if critical Covid-19 is primarily a pulmonary disease - rather than a hematological disease - recovery rates with ECMO would be extremely high. ECMO fails as a universal cure (31) for critical Covid-19 patients; mortality rates of critical Covid-19 patients in receipt of ECMO are reported as: $31 \%$ of 83 (32), 35\% of 124 (33), $41.7 \%$ of 12 (34), $66.7 \%$ of 15 (35), $94.1 \%$ of 17 (36) and $100 \%$ of 3 (37). Causes of death in ECMO patients are typically septic shock and multiple organ failure; these results point to the biomedical insufficiency of hypotheses of Covid-19 as principally a pulmonary disease. Conventional views of Covid-19 as primarily a viral pneumonia also fail to explain the phenomenon of chronic symptomology associated with SARS-Cov-2 infection, known colloquially as 'long Covid'. Persistent symptoms include dyspnoea (43\%), chronic fatigue (53\%), joint pain (27\%), chest pain (22\%), generalised pain and psychiatric problems (38). Numerous alternative hypotheses have been proposed to explain the extra-pulmonary dimensions of the Covid-19 phenotype, including cytokine storm-induced hyperinflammation (29), Kawasaki-like or toxic shock syndrome-like systemic paediatric presentation (39) and systemic thromboembolism (40). Treatment with antiinflammatory and anti-coagulant agents may reduce mortality $(41,42)$ however, to date, there is no globally optimal solution to treatment of critical Covid-19 patients.

\section{Symptomology: neurovisceral, neuromuscular, neurological}

Although highly speculative, porphyria would explain many of the extra-pulmonary symptoms of Covid-19 including neurovisceral, neuromuscular and neurological symptoms. Porphyria, as a phenotype, would also explain why ECMO is inadequate as a treatment for critical patients and may explain the long-term symptomology of Covid-19. To assess the comparative symptomology of SARSCov-1, SARS-Cov-2 and porphyria, literature search was performed, and the results are summarised in Supplementary Table. Overlap between symptomologies was visualised in Venny (91) under both conservative and liberal inclusion criteria (Fig. 2). The result is that: (i) under liberal comparison criteria, sensory loss and paralysis are shared by porphyria and Covid-19 but not SARS1, (ii) under conservative comparison criteria, sensory loss and neuropsychiatric symptoms (and constipation) are shared by porphyria and Covid-19 but not SARS-1. If the porphyria hypothesis were to be confirmed, symptoms of sensory loss, paralysis and neuropsychiatric symptoms would be explained in Covid-19 patients as an outcome of porphyrin excess. Similarity between Covid19 phenotype and acute porphyria can be visualised by comparison with patient and healthcare provider testimonials of the lived experience of acute porhyria, as documented in Clinical Case Series Volume Two - an educational series produced by psychiatrist Dr Andrew Macaulay (92).

\section{Abnormal concentrations of porphyrins in Covid-19}

Moreover, since publication of the original hypothesis, abnormal concentrations of porphyrins have been detected (Table 1) in serum (93) and in the cellular compartment of blood (167). Porphyrin metabolite profile of Covid-19 overlaps (red arrows) with acute porphyria in eight instances and with non-acute porphyria in three instances (Table 1). While San Juan et al state that levels of aminolevulinic acid (ALA) and porphobilinogen (PBG) are not elevated in serum of acute Covid-19 patients, relative to non-Covid pneumonia patients, no data are presented to justify the statement. Further, San Juan et al conclude that the serum porphyrin profile does not match those of porphyrias. This evaluation is inaccurate: plasma porphyrins are markedly increased only in variegate porphyria (VP); however, most types of acute porphyria show normal or only slightly elevated serum porphyrin profiles. 
Diagnosis of acute porphyrias requires urinalysis, rather than serum sample analysis, as demonstrated by The Porphyrias Consortium (94). Further evidence supporting the porphyria hypothesis derives from Pang Z et al (95), whose meta-analysis of metabolomics datasets found that the most significantly perturbed pathway in Covid-19 is porphyrin metabolism, or heme biosynthesis. Further research is required in order to elucidate the extent of concordance between the phenotypes of Covid-19 and porphyria.

\section{Sickle cell protection against Covid-19}

As surmised in version 1 of acute porphyria hypothesis (1) if hemoglobin-targeting is an important component of Covid-19 pathophysiology, susceptibility may differentiate according to hemoglobin phenotype. Epidemiologically, the differentiation may surface as ethnic variation, since hemoglobin phenotype is associated with ethnicity. For example, South-East Asian ethnicities have higher prevalence of haemoglobin E (96); any protective effect of hemoglobin phenotype in Covid-19 would be analogous to maintenance of sickle cell heterozygosity in West African ethnicities as a selective advantage in protecting against malaria. Two studies explicitly suggest a protective effect of sickle cell phenotype in Covid-19 $(97,98)$ and multiple studies report a mild course of disease in sickle cell patients with favorable outcomes and few complications $(99,100,101,102,103,104,105,106,107,108$, $109,110,111,112,113,114,115,116,117)$. Only two studies to date suggest a statistically increased risk of mortality in sickle cell Covid-19 patients relative to non-sickle cell Covid-19 patients $(118,119)$. Both of these studies have considerable limitations; Mucalo et al compared case fatality rates in sickle cell vs non-sickle cell Covid-19 patients and controlled for age. However, there is no mention in Mucalo et al regarding co-morbidities and other demographic risk factors associated with Covid-19. Similarly, Clift et al adjusted for age, sex, and ethnicity but neglected to adjust for co-morbidities. Clift et al is a large Cox regression analysis of 12.28 million citizens; compare this with the findings of AbdulRahman et al (104) which is a multivariate logistic regression analysis of 1,792 patients. While AbdulRahman et al is a smaller cohort study and therefore has potentially less statistical power, the study is appropriately controlled for confounding variables. For example, AbdulRahman et al note that the sickle cell group had a higher prevalence of unrelated co-morbidities that are known risk factors for Covid-19 severity. Specifically, 44.7\% were diagnosed with at least one other comorbidity and $13.2 \%$ had three or more other co-morbidities in contrast to the $24.1 \%$ and $10.4 \%$ respectively in the non-sickle cell group (104).The possibility of confounding variables cannot be denied in either of the two studies that claim increased risk in sickle cell patients. On the whole, sickle cell patients seem to have a slightly elevated risk of hospitalisation with painful splenic crisis, however a lower overall risk of Covid-19 mortality. To many researchers, a potential protective effect of sickle cell disease is unexpected, since sickle cell patients at baseline have numerous traits that would suggest increased risk of Covid19 susceptibility, including: hypercoagulability, anemia, vaso-occlusive crisis, increased risk of infection, increased risk of pneumonia, increased risk of pulmonary vaso-occlusive crisis and acute chest syndrome (97). However, viewed from the perspective of the acquired acute porphyria hypothesis, sickle cell protection against Covid-19 is understandable.

\section{Heme-binding motifs in SARS-Cov-2 proteins}

Preliminary work from the University of Bonn and Fraunhofer Institute (120) suggests multiple potential heme-binding motifs in SARS-Cov-2 proteins, spike and 7a. Initial lists of potential heme-binding motifs were compiled using HeMo Quest, a primary structure-based HBM prediction server, trained on a large array of heme-binding peptides that has $92 \%$ accuracy (120, 121). The initial list was refined on the basis of surface accessibility of the motifs within isomers or oligomers of the proteins. A shortlist of candidate heme-binding motifs (three candidates in spike and two in protein 7a) was subjected to experimental validation by incubation of each SARS-Cov-2 peptide with heme followed by UV spectroscopy analysis. Notably, the spike protein shortlist of HBMs are all present in the N-terminal domain of the S1 subunit and the sequences are: (1) FLGVY144YHKN, 2) IYSKH207TPIN, (3) LHRSY248LTPG. Shortlisted protein 7a HBM sequences are: (1) DGVKH73VYQL, (2) VKHVY75QLRA. Further, SARS-Cov-2 spike protein is conjectured to bind the heme metabolites biliverdin and bilirubin as an immunoevasion mechanism (122), supporting the idea that spike may bind heme.

In complement of the findings of Hopp et al and Rosa et al, the current author performed search for the protein FASTA sequences of heme- binding motifs in NCBI, specifying a motif length of 3-20 amino acids. Search criteria specified in NCBI were: ((heme binding[Protein Name] OR (heme[All Fields] AND binding[All Fields])) AND motif[All Fields]) AND ("3"[SLEN] : "20"[SLEN]). There were 48 results and one (HXXXXH) of these was noticed to be present in SARS-Cov-2 spike protein using Python code (Fig. 4). $\mathrm{HXXXXH}$ is a histidine box that is known, in other proteins, to be involved in iron-binding $(123,124)$. Moreover, various $\mathrm{HX}(\mathrm{n}) \mathrm{H}$ motifs have been shown experimentally to bind heme and act as heme regulatory motifs (125). Further known heme-binding motifs were identified (Table 2) by utilising the same code, including the canonical heme-binding dipeptide cysteine-proline, located within the receptor binding domain (RBD) of spike glycoprotein. Presence of heme regulatory motifs in spike glycoprotein does not automatically imply porphyrin-binding functionality; surface accessibility and physicochemical properties of the spacer residues are important considerations, in the global context of the spike glycoprotein. However, the highlighted sub-sequences represent candidate motifs for further investigation.

\section{Spike induces heme oxygenase-1}

Several authors have contemplated the relevance of heme oxygenase-1 in relation to Covid-19 $(127,128,129,130,131)$. Recently, spike glycoprotein has been suggested to induce the expression of heme oxygenase-1 - the rate limiting enzyme in heme catabolism - in HEK293 kidney cells, implying that disturbance of heme metabolism may characterise the Covid-19 phenotype (132). Taken together with the findings of Rosa et al (122), spike may potentially increase the production of biliverdin, and biliverdin binds spike protein as an immunoevasion mechanism (Fig. 3). 
Two of the most peculiar aspects of the Covid-19 phenotype are: (1) silent hypoxemia, (2) diminished erythropoietin. Both phenomena can be considered as maladaptive oxygen-sensing responses (Fig. 5). Erythropoietin is ordinarily upregulated under conditions of hypoxia via the hypoxia inducible factor (HIF) pathway (153). Incidentally, one known exception to hypoxia-induced erythropoietin production is blockage of heme synthesis (154). Curiously, initial evidence suggests that serum erythropoietin levels are on average 2.5-fold (155) lower in Covid-19 non-survivors when compared with survivors (156). Interestingly, heme proteins are known to act as direct oxygen sensors in multiple microbial species (157), and heme proteins are relevant for oxygen-sensing in silent hypoxemia.

Silent hypoxemia is the clinical phenomenon of dyspnea-free hypoxemia. Carotid body mediates the connection between hypoxemia and dyspnea $(158,159,160)$. Bilateral carotid body resection has been reported anecdotally to relieve dyspnea (158) while carotid body stents and tumors exacerbate dyspnea $(159,160)$. Infection of the carotid body by SARS-Cov-2 has been previously suggested as an explanatory factor underlying silent hypoxemia in Covid-19 $(161,162,163)$ and preliminary autopsy evidence indicates the presence of SARS-Cov-2 in the carotid body (164). Specifically, glomus cells within the carotid body are responsible for sensing hypoxia, a process that requires mitochondrion oxygen sensors acting via cytochrome a3 redox levels (165). Cytochrome a3 contains a heme prosthetic group, heme A, that is necessary for oxygen-sensing (166). As a structural relative of heme $B$, present in hemoglobin, it is conceivable that a common mechanism might disrupt the structural integrity of both heme $A$ and $B$ in Covid-19, leading to concomitant phenotypes of acute porphyria, dyserythropoiesis and silent hypoxemia.

Sensing of oxygen and hypoxia occurs also by heme-independent systemic and cellular mechanisms, including arterial oxygen receptors and the HIF pathway, respectively. Heme-dependent oxygen sensing mechanisms are not definitively affected in Covid19 , but are mentioned here for reasons of pertinence, since homeostatic recovery depends upon the ability of the body to efficiently detect and respond to low oxygen levels.

\section{Nascent treatment mechanisms}

Hydroxychloroquine and, more recently, ivermectin - have been proposed as candidates in the prophylaxis and treatment of Covid-19. The latter has been eloquently advocated by Dr Pierre Kory (133). Mechanisms of action of each drug have been respectively suggested as: (i) interference in the endocytic pathway, blockade of sialic acid receptors, restriction of $\mathrm{pH}$ mediated spike (S) protein cleavage at the angiotensin-converting enzyme 2 (ACE2) binding site and prevention of cytokine storm (134); and (ii) inhibition of SARS-Cov-2 replication (135) by an as-yet undefined mechanism. Ivermectin is mostly associated with anthelmintic binding and activation of glutamate-gated chloride channel receptors, and separately, with antiviral inhibition of importin $\alpha / \beta 1$ heterodimer-mediated nuclear transport (136).

If porphyria is an important component of the Covid-19 phenotype, pharmacological mechanisms relevant to porphyrin metabolism would be expected. Two alternative mechanisms of action are proposed in the event that porphyria is a significant driver of pathology. Firstly, as aforementioned, chloroquine induces the release of tissue-bound porphyrins; the initial event following chloroquine administration to porphyria cutanea tarda (PCT) patients is a release of bound hepatic porphyrin and its rapid elimination (27). Secondly, ivermectin interacts with the transporter ABCG2 (137). ABCG2 is essential for the transport of porphyrins; $A B C G 2$ location at the plasma membrane modulates removal of excess porphyrins from the cell (138). ABCG2 is upregulated by hypoxia and is therefore important in maintaining porphyrin homeostasis in hypoxic cells (138). Therefore, one potential mechanism of ivermectin activity is acceleration of porphyrin clearance via ABCG2 (Fig. 6).

\section{Conclusion}

Since publication of the original hypothesis in April 2020, hematological dimensions of Covid-19 have increasingly become apparent, including hypercoagulability (139) as well as pulmonary vascular endothelialitis, thrombosis and angiogenesis (140). Erythroid progenitors are one possible site of SARS-Cov-2 infection (141) and erythroid precursor cells have been detected in peripheral blood (142). As anticipated, sickle cell patients are protected from Covid-19 complications and mortality, according to preliminary data. Although highly speculative, porphyria would explain many peculiarities of the Covid-19 phenotype including neurovisceral, neuromuscular and neurological symptomology, as well as the phenomenon of 'long Covid'. Hyponatraemia is another hallmark of acute porphyria and systematic reports of hyponatraemia in critical Covid- 19 patients are growing (143, $144,145)$. Exploratory analysis of erythropoiesis and hemoglobin metabolism may provide insight into the nature of the Covid-19 phenotype. Specifically, the author recommends testing the porphyria hypothesis by urinalysis of light-protected samples from critical Covid-19 patients to check for elevated aminolevulinic acid and porphobilinogen. Readily available interventions exist to treat acute porphyria (146) including intravenous heme arginate; intravenous glucose in water solutions are contraindicated due to aggravated hyponatraemia, which can prove fatal (146). Mortality rates for acute porphyria vary by patient population; in an Argentinian population of 102 patients, 15\% with symptomatic acute porphyria died during an acute attack (84). Of the patients who died, respiratory failure induced by the porphyria attack itself was the precipitating factor in $61 \%$ of cases (84). Several recent publications concur that acute porphyria is a feasible hypothesis for the Covid-19 phenotype $(93,147,148,149,150,151,152)$. 
Figure 1. Covid-19 as acquired acute porphyria. There are multiple types of inherited porphyria, each of which affect enzyme functionality in catalysing specific steps in the ultimate conversion of aminolevulinic acid to heme. All the heme precursors are thought to be toxic (4) and the liver is a major site of hemoglobin synthesis. Acute attacks of porphyria are usually associated with hepatic, rather than erythropoietic, involvement. SARS-Cov-2 receptors ACE2 and CD147 are both expressed in the liver (17, 18, 19) and liver is a known target organ of SARS-Cov-2 infection (20). If SARS-Cov-2 disrupts any one or more steps in the heme biosynthesis pathway, porphyria may result; in particular, disruption of the final step may dampen negative feedback control on ALA-synthase.

Supplementary Table. Comparison table of clinical signs and symptoms between SARS-Cov-1, SARS-Cov-2, and porphyria. Combinations of the symptom and disease terms were searched in the title of articles published in any year in Google Scholar; any combinations returning zero hits were cross-checked in PubMed. Between one and ten papers are cited per symptom-disease combination; for some combinations, the availability is greater than reported, and the present data are intended to be indicative rather than exhaustive.

Figure 2. Three-way symptomology comparison between SARS-Cov-1, Covid-19, and porphyria patients (a) liberal comparison (b) conservative comparison. Liberal comparison includes symptoms that have been reported in isolated cases in the literature and that have not necessarily been confirmed as being statistically associated with each condition. Conservative comparison excludes symptoms that are only reported in isolated cases. (a) Eighteen reported symptoms are shared between all three conditions. As expected, Covid-19 has high overlap of symptoms with SARS-1, with the two conditions sharing 22 symptoms and 4 symptoms differing between SARS-1 and Covid-19. The four symptoms that differ will, presumably, provide insight into the pathophysiological novelty of Covid-19 relative to SARS-Cov-1. The four symptoms are: paralysis, anosmia, ageusia and hyperinflammatory syndrome. Note that most of these symptoms have neurological involvement. The symptoms of overlap between Covid-19 and porphyria specifically are paralysis and sensory loss. (b) Similarly, to the liberal comparison, conservative comparison reveals that sensory loss and neuropsychiatric symptoms (and constipation) are shared by Covid-19 and porphyria specifically. As aforementioned, the three symptoms of sensory loss, paralysis and neuropsychiatric disorders have strong neuromuscular and neurological components - and may provide insight into the pathophysiology that is unique to Covid-19, in contrast with SARS-1.

Table 1. Altered heme metabolism in Covid-19. Key: Red arrows indicate overlap, and blue arrows discordance, between metabolite profiles of specific types of porphyria and Covid19.. Abbreviations: AIP, acute intermittent porphyria; HCP, hereditary coproporphyria; VP, variegate porphyria; ADP, delta-aminolevulinic acid (ALA) dehydratase deficiency porphyria; CEP, congenital erythropoietic porphyria; HP, hepatic protoporphyria; EP, erythropoietic protoporphyria; HMBS, hydroxymethylbilane synthase; RBCs, red blood cells; $\mathrm{CO}$, carbon monoxide; $\mathrm{Hb}$, hemoglobin.

Figure 3. Interplay between immunoevasion and acute porhyria. Spike glycoprotein is conjectured to interfere with the formation of heme, leading to loss of negative regulation on ALAS-1 and accumulation of heme precurors, resulting in acute porphyria. Concomitantly, heme precursor protoporphyrin IX is available for Zn2+ incorporation into zinc protoporhyrin. Zinc protoporphyrin competitively inhibits heme oxygenase-1, while spike induces heme oxygenase-1. Heme oxygenase-1 catabolises heme to biliverdin, and biliverdin binding to spike acts as a potential immunoevasion mechanism.

Figure 4. Motif search for HXXXXH in SARS-Cov-2 Spike. Upper: script code imports the module regular expressions. HXXXXH motif is assigned to the variable 'motif' and the FASTA protein sequence of SARS-Cov-2 is assigned to the object 'protein' prior to motif search. Lower: output shows the position of histidine box origin as residue 1082 in spike.

Table 2. Tabular overview of sub-sequences identified within SARS-Cov-2 surface glycoprotein. Corresponding generic hemebinding motif structures are shown in the second column and sources of the generic motifs are listed on the RHS. Origin position of sub-sequences within the global spike glycoprotein are given in the middle column and the fourth column cites the region of spike in which the sub-sequence is located. Regions: NTD, N-terminal domain; RBD, receptor binding domain; S2, S2 domain.

Figure 5. Impairment of heme-based oxygen sensing. There are two main heme-based responses to hypoxemia and hypoxia that are relevant to Covid-19. Firslty, heme $A$ within mitochondrial cytochrome a3 mediates oxygen sensing in glomus cells of the carotid body. Hypoxia is detected within glomus cells and a message relayed to the brain that results in the patient's subjective feeling of dyspnea. Secondly, erythropoietin is induced in response to hypoxia, except in case of heme biosynthesis blockage by succinylacetone. Taken together, SARS-Cov-2 appears to both: (i) induce hypoxemia and hypoxia; and, (ii) inhibit homeostatic mechanisms that have evolved to correct for hypoxemia and hypoxia.

Figure 6. Putative drug actions in Covid-19. LHS: chloroquine has been known since the 1970s to promote clearance of hepatic tissue-bound porphyrins via porphyrinuria. RHS: ivermectin interacts with the porphyrin transporter ABCG2 and may accelerate porphyrin export. PBG, porphobilinogen; PPIX, protoporphyrin IX. 
The author reports no conflict of interest

Acknowledgements

The author thanks the Ronin Institute for their affiliation and Dr. Cameron Kyle Sidell for his moral courage.

\section{References}

1. Abrahams L. 2020. Covid-19: acquired acute porphyria hypothesis. OSF; https://doi.org/10.31219/osf.io/fxz3p.

2. Gong J, Ou J, Qiu X, et al. A Tool to Early Predict Severe 2019-Novel Coronavirus Pneumonia (COVID-19): A Multicenter Study using the Risk Nomogram in Wuhan and Guangdong, China. 2020; MedRxiv doi.org/10.1101/2020.03.17.20037515

3. Patel HH, Patel HR, Higgins JM. 2015. Modulation of red blood cell population dynamics is a fundamental homeostatic response to disease. American Journal of Hematology, 90(5):422-428.

4. Sassa S. 2006. Modern diagnosis and management of the porphyrias. British Journal of Haematology, 135: $281-292$.

5. Munster VJ, Feldmann F, Williamson BN, van Doremalen N, Pérez-Pérez L, Schulz J, Meade-White K, Okumura A, Callison J, Brumbaugh B, Avanzato VA. 2020. Respiratory disease in rhesus macaques inoculated with SARS-CoV-2. Nature, 585(7824):268-72.

6. Zhao J, Yang Y, Huang H, Li D, Gu D, Lu X, Zhang Z, Liu L, Liu T, Liu Y, He Y. 2021. Relationship between the ABO blood group and the coronavirus disease 2019 (COVID-19) susceptibility. Clinical Infectious Diseases, 73(2):328-31.

7. Guillon P, Clément M, Sébille V, et al. Inhibition of the interaction between the SARS-CoV spike protein and its cellular receptor by anti- histo-blood group antibodies. Glycobiology 2008; 18 (12): 1085-1093

8. Wang K, Chen W, Zhang Z, Deng Y, Lian JQ, Du P, Wei D, Zhang Y, Sun XX, Gong L, Yang X. 2020. CD147-spike protein is a novel route for SARS-CoV-2 infection to host cells. Signal transduction and targeted therapy, 5(1):1-10.

9. Crosnier C, Bustamante LY, Bartholdson SJ, et al. Basigin is a receptor essential for erythrocyte invasion by Plasmodium falciparum. Nature 2011; 480: 534-537

10. Coste I, Gauchat JF, Wilson A, et al. Unavailability of CD147 leads to selective erythrocyte trapping in the spleen. Blood 2001; 97 (12): 3984-3988

11. Feng Z, Diao B, Wang R, et al. The novel severe acute respiratory syndrome coronavirus 2 (SARS-CoV-2) directly decimates human spleens and lymph nodes. 2020; medRxiv, doi.org/10.1101/2020.03.27.20045427

12. Dale DC. The mysteries of the spleen. Journal of Leukocyte Biology 2016; 100 (2): 249-25

13. Chen N, Zhou M, Dong X, et al. Epidemiological and clinical characteristics of 99 cases of 2019 novel coronavirus pneumonia in Wuhan, China: a descriptive study. The Lancet 2020; 395 (10223): 507-513

14. Sulovska L, Holub D, Zidova Z, Divoka M, Hajduch M, Mihal V, Vrbkova J, Horvathova M, Pospisilova D. 2016. Characterization of iron metabolism and erythropoiesis in erythrocyte membrane defects and thalassemia traits. Biomedical Papers, 160(2):231-237.

15. Trier H, Krishnasamy VP, Kasi PM. 2013. Clinical manifestations and diagnostic challenges in acute porphyrias. Case Reports in Hematology, doi.org/10.1155/2013/628602.

16. Liu W, Li H. 2020. COVID-19: Attacks the 1-Beta Chain of Hemoglobin and Captures the Porphyrin to Inhibit Human Heme Metabolism. ChemRxiv, doi.org/10.26434/chemrxiv.11938173.v5

17. Wu SJ, Huo LJ, Zhang J, Wang JJ, Jia H. 2014. Differential expression in ACE2, Ang (1-7) and Mas receptor during progression of liver fibrosis in a rat model. Chinese journal of hepatology, 22(2):118-21.

18. Stebbing J, Nievas GS, Falcone M, Youhanna S, Richardson P, Ottaviani S, Shen JX, Sommerauer C, Tiseo G, Ghiadoni L, Virdis A. 2021. JAK inhibition reduces SARS-CoV-2 liver infectivity and modulates inflammatory responses to reduce morbidity and mortality. Science Advances, 7(1):eabe4724.

19. Li HY, Ju D, Zhang DW, Li H, Kong LM, Guo Y, Li C, Wang XL, Chen ZN, Bian H. 2015. Activation of TGF- $\beta 1-C D 147$ positive feedback loop in hepatic stellate cells promotes liver fibrosis. Scientific Reports, 12;5(1):1-4.

20. Wang Y, Liu S, Liu H, Li W, Lin F, Jiang L, Li X, Xu P, Zhang L, Zhao L, Cao Y. 2020. SARS-CoV-2 infection of the liver directly contributes to hepatic impairment in patients with COVID-19. Journal of Hepatology, 73(4):807-816. 
21. Pischik E, Kauppinen R. 2015. An update of clinical management of acute intermittent porphyria. The Application of Clinical Genetics, 8: 201

22. Poggiali E, Ramos PM, Bastoni D, Vercelli A, Magnacavallo A. 2020. Abdominal pain: a real challenge in novel COVID-19 infection. European Journal of Case Reports in Internal Medicine, 7 (4) doi: 10.12890/2020_001632

23. Zhao K, Huang J, Dai D, Feng Y, Liu L, Nie S. 2020. Acute myelitis after SARS-CoV-2 infection: a case report. medRxiv, doi.org/10.1101/2020.03.16.20035105

24. Mao L, Wang M, Chen S, He Q, Chang J, Hong C, Zhou Y, Wang D, Li Y, Jin H, Hu B. 2020. Neurological manifestations of hospitalized patients with COVID-19 in Wuhan, China: a retrospective case series study. medRxiv, 10.1101/2020.02.22.20026500

25. Laiwah AC, Macphee GJ, Boyle P, Moore MR, Goldberg A. 1985. Autonomic neuropathy in acute intermittent porphyria. Journal of Neurology, Neurosurgery \& Psychiatry, 48(10):1025-30.

26. Blauvelt A. Hepatitis C Virus and Human Immunodeficiency Virus can alter porphyrin metabolism and lead to porphyria cutanea tarda. Archives of Dermatology 1996; 132 (12): 1503-1504

27. Scholnick PL, Epstein J, Marver HS. 1973. The Molecular Basis of the Action of Chloroquine in Porphyria Cutanea Tarda. Journal of Investigative Dermatology, 61(4):226-232.

28. Hansen M. How Covid-19 Kills Some People But Not Others; 2020 Apr 15 [cited 2021 Nov 05]. Available from: https://www.youtube.com/watch?v=LV8wWhjTKRU.

29. Mehta P, McAuley DF, Brown M, Sanchez E, Tattersall RS, Manson JJ. 2020. COVID-19: consider cytokine storm syndromes and immunosuppression. Lancet 2020; 395: 1033-4

30. Sidell CK. From NYU ICU: Does Covid-19 really cause ARDS? 2020 Mar 31 [cited 2021 Nov 05]. Available at: https://www.youtube.com/watch?v=k9GYTc53r2o.

31. Kingston EV. High rates of stillbirth and preterm delivery in women with covid-19 and the efficacy of ECMO in pregnancy. British Medical Journal 2020; 370, doi.org/10.1136/bmj.m2921

32. Schmidt M, Hajage D, Lebreton G, Monsel A, Voiriot G, Levy D, Baron E, Beurton A, Chommeloux J, Meng P, Nemlaghi S. 2020. Extracorporeal membrane oxygenation for severe acute respiratory distress syndrome associated with COVID-19: a retrospective cohort study. The Lancet Respiratory Medicine, 8(11):1121-31.

33. Combes A, Hajage D, Capellier G, et al. Extracorporeal Membrane Oxygenation for Severe Acute Respiratory Distress Syndrome. New England Journal of Medicine 2018; 378: 1965-1975

34. Zeng Y, Cai Z, Xianyu Y, Yang BX, Song T, Yan Q. 2020. Prognosis when using extracorporeal membrane oxygenation (ECMO) for critically ill COVID-19 patients in China: a retrospective case series. Critical Care, 24(1):1-3.

35. Jacobs JP, Stammers AH, Louis JS, et al. Extracorporeal membrane oxygenation in the treatment of severe pulmonary and cardiac compromise in coronavirus disease 2019: Experience with 32 patients. 2020; Asaio Journal, doi: 10.1097/MAT.0000000000001185

36. Henry BM, Lippi G. Poor survival with extracorporeal membrane oxygenation in acute respiratory distress syndrome (ARDS) due to coronavirus disease 2019 (COVID-19): Pooled analysis of early reports. Journal of Critical Care 2020; 58: 27-28

37. Campioli CC, Cevallos EC, Assi M, Patel R, Binnicker MJ, O'Horo JC. Clinical predictors and timing of cessation of viral RNA shedding in patients with COVID-19. Journal of Clinical Virology 2020 130: 104577

38. Mahase E. 2020. Covid-19: What do we know about long covid? British Medical Journal 370 doi.org/10.1136/bmj.m2815

39. Rogo T, Mathur K, Purswani M. 2020. Systemic Inflammation with Cardiac Involvement in Pediatric Patients with Evidence of COVID-19 in a Community Hospital in the Bronx, New York. Journal of the Pediatric Infectious Diseases Society, 9(4):502503.

40. Mahajan P, Dass B, Radhakrishnan N, McCullough PA. 2020. COVID-19-Associated Systemic Thromboembolism: A Case Report and Review of the Literature. Cardiorenal Medicine, 10: 462-469.

41. Cano EJ, Fuentes XF, Campioli CC. Impact of corticosteroids in COVID-19 outcomes: systematic review and meta-analysis. Chest 2020; doi.org/10.1016/j.chest.2020.10.054

42. Carfora V, Spiniello G, Ricciolino R, et al. Anticoagulant treatment in COVID-19: a narrative review. Journal of Thrombosis and Thrombolysis, 2020; doi.org/10.1007/s11239-020-02242-0 
43. World Health Organization. 2003. Outbreak news: severe acute respiratory syndrome (SARS). Weekly Epidemiological Record, 78 (12):81-83.

44. Lee N, Hui D, Wu A, Chan P, Cameron P, Joynt GM, Ahuja A, Yung MY, Leung CB, To KF, Lui SF. 2003. A major outbreak of severe acute respiratory syndrome in Hong Kong. New England Journal of Medicine, 348(20):1986-94.

45. Bitnun A, Allen $\mathrm{U}$, Heurter $\mathrm{H}$, et al. Children hospitalized with severe acute respiratory syndrome-related illness in Toronto. Pediatrics 2003; 112: e261-8

46. Hon KL, Leung CW, Cheng WT, et al. Clinical presentations and outcome of severe acute respiratory syndrome in children. Lancet 2003; 361: 1701-3

47. Hui DS, Wong PC, Wang C. SARS: clinical features and diagnosis. Respirology 2003; 8: S20-S24

48. Booth CM, Matukas LM, Tomlinson GA, et al. Clinical features and short-term outcomes of 144 patients with SARS in the greater Toronto area. Jama 2003; 289 (21): 2801-2809

49. Yin Y, Wunderink RG. 2018. MERS, SARS and other coronaviruses as causes of pneumonia. Respirology, 23(2):130-137.

50. Chiu WK, Cheung PC, Ng KL, et al. severe acute respiratory syndrome in children: Experience in a regional hospital in Hong Kong. Pediatric Critical Care Medicine 2003; 4: 279-83

51. Lai $B, \mathrm{Xu} \mathrm{H}$, Huang C. Diarrhea as the earliest symptom of severe acute respiratory syndrome (SARS) and the damage of cellular immunity; 2004 [cited 2021 Nov 05]. Available from: http://en.cnki.com.cn/Article_en/CJFDTotalLZBJ200405000.htm.

52. Lin L, Xu YJ, He DP, Han Y, Tang GH, Yang ZM, Yu H, Lin ZX. 2003. A retrospective study on clinical features of and treatment methods for 77 severe cases of SARS. The American Journal of Chinese Medicine, 1(6):821-839.

53. Jin-pan Z, Bao-jin H, Chang-huai C, et al. Clinical characteristics of 42 SARS patients and their treatment of integrative Chinese and western medicine. Chinese Journal of Integrative Medicine 2003; 9 (3):169-174

54. Sheng B, Cheng SK, Lau KK, Li HL, Chan EL. 2005. The effects of disease severity, use of corticosteroids and social factors on neuropsychiatric complaints in severe acute respiratory syndrome (SARS) patients at acute and convalescent phases. European psychiatry, 20(3):236-242.

55. Hui DS, Wong KT, Antonio GE, Tong M, Chan DP, Sung JJ. Long-term sequelae of SARS: physical, neuropsychiatric, and quality-of-life assessment. Hong Kong Medical Journal 2009; 15: 21

56. Lau AC, Yam LY, So LK. 2004. Management of critically ill patients with severe acute respiratory syndrome (SARS). International Journal of Medical Sciences, 1(1):1-10.

57. Chong PY, Chui $P$, Ling $A E$, et al. Analysis of deaths during the severe acute respiratory syndrome (SARS) epidemic in Singapore: challenges in determining a SARS diagnosis. Archives of Pathology \& Laboratory Medicine 2004; 128 (2): $195-204$

58. Wong RS, Wu A, To KF, Lee N, Lam CW, Wong CK, Chan PK, Ng MH, Yu LM, Hui DS, Tam JS. 2003. Haematological manifestations in patients with severe acute respiratory syndrome: retrospective analysis. BMJ, 326(7403):1358-62.

59. Yu CM, Wong RS, Wu EB, Kong SL, Wong J, Yip GW, Soo YO, Chiu ML, Chan YS, Hui D, Lee N. 2006. Cardiovascular complications of severe acute respiratory syndrome. Postgraduate Medical Journal, 82(964):140-4.

60. Garg S, Kim L, Whitaker M, et al. Hospitalization Rates and Characteristics of Patients Hospitalized with LaboratoryConfirmed Coronavirus Disease. Morbidity \& Mortality Weekly Report 2020; 69: 458-464

61. Chen J, Qi T, Liu L, et al. Clinical progression of patients with COVID-19 in Shanghai, China. Journal of Infection 2020 ; 80 (5): e1-e6

62. Takeuchi T, Imanaka T, Katayama Y, Kitamura T, Sobue T, Shimazu T. 2020. Profile of patients with novel coronavirus disease 2019 (COVID-19) in Osaka Prefecture, Japan: a population-based descriptive study. Journal of Clinical Medicine, (9):2925.

63. Hopkinson NS, Rossi N, Moustafa JE, et al. Current tobacco smoking and risk from COVID-19: results from a population symptom app in over 2.4 million people. 2020; medRxiv doi.org/10.1101/2020.05.18.20105288

64. Menni C, Valdes AM, Freidin MB, Sudre CH, Nguyen LH, Drew DA, Ganesh S, Varsavsky T, Cardoso MJ, Moustafa JS, Visconti A. 2020. Real-time tracking of self-reported symptoms to predict potential COVID-19. Nature Medicine, 26(7):1037-1040.

65. Pan L, Mu M, Yang P, Sun Y, Wang R, Yan J, Li P, Hu B, Wang J, Hu C, Jin Y. 2020. Clinical characteristics of COVID-19 patients with digestive symptoms in Hubei, China: a descriptive, cross-sectional, multicenter study. The American Journal of Gastroenterology, 115: 10.14309/ajg.0000000000000620. 
66. Chow CC, Magnussen J, Ip J, Su Y. Acute transverse myelitis in COVID-19 infection. BMJ Case Reports 2020; 13 (8): e236720

67. Álvarez-Troncoso J, Larrauri MZ, Vega MD, Vallano RG, Peláez EP, Rojas-Marcos PM, Martín-Luengo F, Del Campo PL, Gil CR, Esteban ET. 2020. Case report: COVID-19 with bilateral adrenal hemorrhage. The American Journal of Tropical Medicine and Hygiene, 103(3):1156.

68. Saniasiaya J, Kulasegarah J. 2021. Dizziness and COVID-19. Ear, Nose \& Throat Journal, 100(1):29-30.

69. Maurier F, Godbert B, Perrin J. 2020. Respiratory Distress in SARS-CoV-2 without Lung Damage: Phrenic Paralysis Should Be Considered in COVID-19 Infection. European Journal of Case Reports in Internal Medicine, 7 (6): 001728.

70. Figueiredo R, Falcão V, Pinto MJ, Ramalho C. Peripheral facial paralysis as presenting symptom of COVID-19 in a pregnant woman. BMJ Case Reports 2020; 13: e237146

71. Casas E, Barbosa A, Rubio-Garcia E, et al. Isolated peripheral facial paralysis in a patient with Covid-19. Revista de Neurologia 2020; 71(1) doi.org/10.33588/RN.7101.2020229

72. Bilaloglu S, Aphinyanaphongs Y, Jones S, Iturrate E, Hochman J, Berger JS. Thrombosis in Hospitalized Patients With COVID19 in a New York City Health System. JAMA 2020; 324 (8):799-801

73. Wang D, Hu B, Hu C, Zhu F, Liu X, Zhang J, Wang B, Xiang H, Cheng Z, Xiong Y, Zhao Y. 2020. Clinical characteristics of 138 hospitalized patients with 2019 novel coronavirus-infected pneumonia in Wuhan, China. JAMA, 323(11):1061-1069.

74. Miglis MG, Prieto T, Shaik R, Muppidi S, Sinn DI, Jaradeh S. 2020. A case report of postural tachycardia syndrome after COVID-19. Clinical Autonomic Research, 30: 449-451.

75. Umapathi T, Poh MQ, Fan BE, Li KF, George J, Tan JY. 2020. Acute hyperhidrosis and postural tachycardia in a COVID-19 patient. Clinical Autonomic Research, doi.org/10.1007/s10286-020-00733-x.

76. Mitacchione G, Schiavone M, Gasperetti A, Forleo GB. Ventricular tachycardia storm management in a COVID-19 patient: a case report. European Heart Journal - Case Reports 2020; 4 (FI1): 1-6

77. Babapoor-Farrokhran S, Port Z, Wiener PC, Amanullah A, Mainigi SK. 2020. Polymorphic Ventricular Tachycardia with a Normal QTc Interval in a Patient with COVID-19 and Fever: Case Report. SN Comprehensive Clinical Medicine, 2(11):2387-90.

78. Reddy V, Reddy V, Mangat S, Shokr M, Kundumadam S, Laharwani H. 2020. Wide complex tachycardia in a COVID-19 patient: What is the mechanism? Journal of Electrocardiology, 60: 200-202

79. Riphagen S, Gomez X, Gonzalez-Martinez C, Wilkinson N, Theocharis P. 2020. Hyperinflammatory shock in children during COVID-19 pandemic. The Lancet, 395(10237):1607-1608.

80. Hay RJ. A viral rash: the impact of COVID-19 infection on the skin. British Journal of Dermatology 2020; 183 (1):1-2

81. Cohen PL, Hadler NM, Starkenburg R. Acute intermittent porphyria presenting as acute muscle pain, fever, and weakness. Arthritis \& Rheumatology 2005; 40 (3): 586-588

82. Bylesjö I, Wikberg A, Andersson C. Clinical aspects of acute intermittent porphyria in northern Sweden: A populationbased study. Scandinavian journal of clinical and laboratory investigation, 69(5), pp.612-618.30.

83. Quansah R, Cooper CJ, Said S, Bizet J, Paez D, Hernandez GT. 2014. Hepatitis C- and HIV-induced porphyria cutanea tarda. American Journal of Case Reports, 5: 35-40

84. De Siervi A, Rossetti MV, Parera VE, Mendez M, Varela LS, Batlle AM. Acute intermittent porphyria: Biochemical and clinical analysis in the Argentinean population. Clinica Chimica Acta 1999; 288: 63-71

85. Andersson C, Innala E, Bäckström T. 2003. Acute intermittent porphyria in women: clinical expression, use and experience of exogenous sex hormones. A population-based study in northern Sweden. Journal of internal medicine, 254(2):176-83.

86. Yang, Y., Chen, X., Wu, H., Peng, H., Sun, W., He, B. and Yuan, Z., 2020. A novel heterozygous mutation in the HMBS gene in a patient with acute intermittent porphyria and posterior reversible encephalopathy syndrome. Molecular medicine reports, 22(1), pp.516-524.

87. Kauppinen R. Porphyrias. Lancet 2005; 365: 241-52

88. Solinas C, Vajda FJE. 2008. Neurological complications of porphyria. Journal of Clinical Neuroscience, 15 (3): $263-268$.

89. Dowman JK, Gunson BK, Mirza DF, et al. Liver transplantation for acute intermittent porphyria is complicated by a high rate of hepatic artery thrombosis. Liver Transplantation 2012; 18 (2): 195-200 
90. Andersen J, Gjengedal E, Sandberg S, Råheim M. 2015. A skin disease, a blood disease or something in between? An exploratory focus group study of patients' experiences with porphyria cutanea tarda. British Journal of Dermatology, 172(1):223-9.

91. Oliveros JC. VENNY: an interactive tool for comparing lists with Venn Diagrams, 2007 [updated 2015; cited 2021 Nov 05]. Available from: https://bioinfogp.cnb.csic.es/tools/venny/index.html.

92. Macaulay A. Clinical Case Studies Volume Two: Porphyria - The Psychiatric Perspective [Internet]. Mental Health TV; 2016 Feb 18 [cited 2021 Dec 25]. Available from: https://www.youtube.com/watch?v=kTKyYxp-FiBA\&t=9s

93. San Juan I, Bruzzone C, Bizkarguenaga M, Bernardo-Seisdedos G, Laín A, Gil-Redondo R, Diercks T, Gil-Martínez J, Urquiza P, Arana E, Seco M. 2020. Abnormal concentration of porphyrins in serum from COVID-19 patients. British Journal of Haematology, 190(5):e265-e267.

94. The Porphyrias Consortium. Laboratory diagnosis of the porphyrias, 2021 [cited 2021 Nov 05]. Available from: https://www.rarediseasesnetwork.org/cms/porphyrias/Healthcare Professionals/diagnosis.

95. Pang Z, Zhou G, Chong J, Xia J. 2021. Comprehensive Meta-Analysis of COVID-19 Global Metabolomics Datasets. Metabolites, 11(1):44.

96. Ha, J., Martinson, R., Iwamoto, S.K. and Nishi, A., 2019. Hemoglobin E, malaria and natural selection. Evolution, medicine, and public health, 2019(1), pp.232-241.

97. Ramachandran P, Perisetti A, Kathirvelu B, Gajendran M, Ghanta S, Onukogu I, Lao T, Anwer F. Low morbidity and mortality with COVID-19 in sickle cell disease: A single center experience. EJHaem. 2020 Nov;1(2):608-14.

98. Arlet JB, de Luna G, Khimoud D, Odièvre MH, de Montalembert M, Joseph L, Chantalat-Auger C, Flamarion E, Bartolucci P, Lionnet F, Monnier S. Prognosis of patients with sickle cell disease and COVID-19: a French experience. The Lancet Haematology 2020 Sep 1;7(9):e632-4.

99. Appiah-Kubi A, Acharya S, Levy CF, Vlachos A, Ostovar G, Murphy K, Farrell A, Brower D, Lipton JM, Wolfe L, Aygun B. Varying presentations and favourable outcomes of COVID-19 infection in children and young adults with sickle cell disease: an additional case series with comparisons to published cases. British Journal of Haematology. 2020 Aug 1.

100. Chakravorty S, Padmore-Payne G, Ike F, Tshibangu V, Graham C, Rees D, Stuart-Smith S. COVID-19 in patients with sickle cell disease-a case series from a UK tertiary hospital. Haematologica. 2020 Nov 1;105(11):2691.

101. Hussain FA, Njoku FU, Saraf SL, Molokie RE, Gordeuk VR, Han J. COVID-19 infection in patients with sickle cell disease. British Journal of Haematology 2020; doi: 10.1111/bjh.16734

102. Silva-Pinto AC, Santos-Oliveira L, Santos FL, Haddad SK, De Santis GC, do Tocantins Calado R. COVID-19 Infection in Sickle Cell Patients in a Developing Country: A Case Series. Acta Haematologica. 2021 Sep 17:1-4.

103. AbdulRahman A, AIAli S, Yaghi O, Shabaan M, Otoom S, Atkin SL, AlQahtani M. COVID-19 and sickle cell disease in Bahrain. International Journal of Infectious Diseases. 2020 Dec 1;101:14-6.

104. Abdulrahman A, Wael M, Alammadi F, Almosawi Z, AlSherooqi R, Abduljalil M, Kumar N, AlQahtani M. Is sickle cell disease a risk factor for severe COVID-19: a multicenter national retrospective cohort. medRxiv. 2021 Jan 1:2020-12.

105. Singh A, Brandow AM, Panepinto J. COVID-19 outcomes in individuals with sickle cell disease and sickle cell trait compared to blacks without sickle cell disease or trait. Blood. 2020 Nov 5;136:54-6.

106. Balanchivadze N, Kudirka AA, Askar S, Almadhoun K, Kuriakose P, Fadel R, Dabak V. Impact of COVID-19 Infection on 24 patients with sickle cell disease. one center urban experience, Detroit, MI, USA. Hemoglobin. 2020 Jul 3;44(4):284-9.

107. Sayad B, Karimi M, Rahimi Z. Sickle cell disease and COVID-19: Susceptibility and severity. Pediatric Blood \& Cancer. 2021 Jun 1:e29075.

108. Hardy YO, Amenuke DA, Abukari Y, Oti-Acheampong A, Hutton-Mensah K, Amoah-Dankwah J, Amoabeng Kontoh S, Danso KA, Berchie PO, Otu-Ansah C. Clinical presentations and outcomes of COVID-19 infection in sickle cell disease patients: Case series from Komfo Anokye teaching hospital, Ghana. Clinical Case Reports. 2021 Feb;9(2):1018-23.

109. Hoogenboom WS, Fleysher R, Soby S, Mirhaji P, Mitchell WB, Morrone KA, Manwani D, Duong TQ. Individuals with sickle cell disease and sickle cell trait demonstrate no increase in mortality or critical illness from COVID-19-A fifteen hospital observational study in the Bronx, New York. Haematologica. 2020.

110. Sewaralthahab S, Smith H. Outcomes of Sickle Cell Disorders in COVID-19 Infection: An Institutional Experience. Blood. 2020 Nov 5;136:30-1. 
111. Noisette L, Mandava M, Gregoski M, Bergmann S. Sickle Cell Disease Related Outcomes in Patients Evaluated for COVID19 Infections in South Carolina. Blood. 2020 Nov 5;136:38-9.

112. Mazloom A, Nimkar N, Paul S, Baptiste A. Clinical Course and Outcomes of Sickle Cell Disease Patients with COVID-19 at a New York Hospital. Blood. 2020 Nov 5;136:34-6.

113. Brousse V, Holvoet L, Pescarmona R, Viel S, Perret M, Visseaux B, Ferre VM, Ithier G, Le Van Kim C, Benkerrou M, Missud F. Low incidence of COVID-19 severe complications in a large cohort of children with sickle cell disease: a protective role for basal interferon-1 activation?. Haematologica 2020.

114. Al-Naami AQ, Khan LA, Zaidan FI, Halawi HM, Asiri LE, Sumaili TA, Qaisi AA, Darweesh TM, Al-Neami IA. Sickle Cell Disease (SCD) and COVID-19-A Case Series. Research Square, 2020; doi https://doi.org/10.21203/rs.3.rs-127636/v1.

115. Rahimi Z, Sayad B. Sickle Cell Disease and COVID-19: Susceptibility and Severity. 2020 Authorea Preprints, doi: 10.22541/au.160645872.24086101/v1

116. McCloskey KA, Meenan J, Hall R, Tsitsikas DA. COVID-19 infection and sickle cell disease: a UK centre experience. British journal of haematology. $2020 \mathrm{Jul} ; 190(2): \mathrm{e} 57-8$.

117. Al Sabahi A, Al Maskari N, Al Busaidi I, Albiroty KA, Alkhamisy A, Al Hinai K, Al Hinai M, Al Mashaikhi N, Alkendi J. Coronavirus Disease 2019 Infection in Children With Sickle Cell Disease: Case Series From Oman. J Pediatr Hematol Oncol. 2021 Oct 1;43(7):e975-e978. doi: 10.1097/MPH.0000000000002061. PMID: 33512869.

118. Clift AK, Saatci D, Coupland CA, Dambha-Miller H, Hippisley-Cox J, International Investigator Group for Ethnicity and COVID-19. Sickle Cell Disorders and Severe COVID-19 Outcomes: A Cohort Study. Annals of Internal Medicine. 2021 Jul 20.

119. Mucalo L, Brandow AM, Mason SF, Singh A, Taylor BW, Woods KJ, Yusuf FI, Panepinto J. Hospitalization and case fatality in individuals with sickle cell disease and COVID-19 infection. Blood. 2020 Nov 5;136:7-8.

120. Hopp MT, Domingo-Fernandez D, Gadiya Y, et al. Linking COVID-19 and heme-driven pathophysiologies: A combined computational- experimental approach, 18 March 2021, Preprint (Version 1) available at Research Square [https://doi.org/10.21203/rs.3.rs-319973/v1]

121. Paul George AA, Lacerda M, Syllwasschy BF, Hopp MT, Wißbrock A, Imhof D. 2020. HeMoQuest: a webserver for qualitative prediction of transient heme binding to protein motifs. BMC Bioinformatics, 21: 124

122. Rosa A, Pye VE, Graham C, Muir L, Seow J, Ng KW, Cook NJ, Rees-Spear C, Parker E, Dos Santos MS, Rosadas C. 2021. SARS-CoV-2 can recruit a heme metabolite to evade antibody immunity. Science Advances, 7(22):eabg7607.

123. Hsieh SL, Chang HT, Wu CH, Kuo CM. Cloning, tissue distribution and hormonal regulation of stearoyl-CoA desaturase in tilapia, Oreochromis mossambicus. Aquaculture 2004; 230 (1-4): 527-546

124. Hasan MA, Ahmed S, Kim Y. Biosynthetic pathway of arachidonic acid in Spodoptera exigua in response to bacterial challenge. Insect Biochemistry and Molecular Biology 2019; 111: 103179

125. Syllwasschy BF, Beck MS, Družeta I, Hopp MT, Ramoji A, Neugebauer U, Nozinovic S, Menche D, Willbold D, Ohlenschläger O, Kühl T. 2020. High-affinity binding and catalytic activity of His/Tyr-based sequences: Extending heme-regulatory motifs beyond CP. Biochimica et Biophysica Acta (BBA)-General Subjects, 1864(7):129603.

126. Kühl T, Wißbrock A, Goradia N, et al. Analysis of Fe (III) heme binding to cysteine-containing heme-regulatory motifs in proteins. ACS Chemical Biology 2013; 8 (8): 1785-1793

127. Wagener, F.A., Pickkers, P., Peterson, S.J., Immenschuh, S. and Abraham, N.G., 2020. Targeting the heme-heme oxygenase system to prevent severe complications following COVID-19 infections. Antioxidants, 9(6), p.540.

128. Batra, N., De Souza, C., Batra, J., Raetz, A.G. and Yu, A.M., 2020. The HMOX1 Pathway as a Promising Target for the Treatment and Prevention of SARS-CoV-2 of 2019 (COVID-19). International journal of molecular sciences, 21(17), p.6412.

129. Rossi, M., Piagnerelli, M., Van Meerhaeghe, A. and Boudjeltia, K.Z., 2020. Heme oxygenase-1 (HO-1) cytoprotective pathway: A potential treatment strategy against coronavirus disease 2019 (COVID-19)-induced cytokine storm syndrome. Medical hypotheses, 144, p.110242.

130. Su, W.L., Lin, C.P., Hang, H.C., Wu, P.S., Cheng, C.F. and Chao, Y.C., 2021. Desaturation and heme elevation during COVID19 infection: A potential prognostic factor of heme oxygenase-1. Journal of Microbiology, Immunology and Infection, 54(1), pp.113-116.

131. Singh, D., Wasan, H. and Reeta, K.H., 2020. Heme oxygenase-1 modulation: A potential therapeutic target for COVID-19 and associated complications. Free Radical Biology and Medicine, 161, pp.263-271. 
132. Singh, R.D., Barry, M.A., Croatt, A.J., Ackerman, A.W., Grande, J.P., Diaz, R.M., Vile, R.G., Agarwal, A. and Nath, K.A., 2021. The spike protein of SARS-CoV-2 virus induces heme oxygenase-1: Pathophysiologic implications. Biochimica et Biophysica Acta (BBA)-Molecular Basis of Disease, p.166322.

133. Kory P. Covid-19 Silver Bullet? Front Line Covid-19 Critical Care Alliance testifies to the Senate Committee; 2020 Dec 08 [cited 2021 Nov 05]. Available from: https://covid19criticalcare.com/senate-testimony/.

134. Satarker S, Ahuja T, Banerjee M, Dogra S, Agarwal T, Nampoothiri M. 2020. Hydroxychloroquine in COVID-19: Potential Mechanism of Action Against SARS-CoV-2. Current Pharmacology Reports, 6: 203-211 doi.org/10.1007/s40495-020-00231-8

135. Caly L, Druce JD, Catton MG, Jans DA, Wagstaff KM. The FDA-approved Drug Ivermectin inhibits the replication of SARSCoV-2 in vitro. Antiviral Research 2020; 3:104787

136. Rizzo E. 2020. Ivermectin, antiviral properties and COVID-19: a possible new mechanism of action. NaunynSchmiedeberg's Archives of Pharmacology, 393: 1153-1156.

137. Jani M, Makai I, Kis E, et al. Ivermectin interacts with human ABCG2. Journal of Pharmaceutical Sciences 2011; 100 (1): 94-97

138. Krishnamurthy $P$, Schuetz JD. The role of $A B C G 2$ and $A B C B 6$ in porphyrin metabolism and cell survival. Current Pharmaceutical Biotechnology 2011; 12 (4): 647-655

139. Panigada M, Bottino N, Tagliabue P, Grasselli G, Novembrino C, Chantarangkul V, Pesenti A, Peyvandi F, Tripodi A. 2020. Hypercoagulability of COVID-19 patients in intensive care unit: a report of thromboelastography findings and other parameters of hemostasis. Journal of Thrombosis and Haemostasis, 18(7):1738-1742.

140. Ackermann M, Verleden SE, Kuehnel M, Haverich A, Welte T, Laenger F, Vanstapel A, Werlein C, Stark H, Tzankov A, Li WW. 2020. Pulmonary vascular endothelialitis, thrombosis, and angiogenesis in Covid-19. New England Journal of Medicine. $383(2): 120-8$.

141. Shahbaz S, Xu L, Osman M, Sligl W, Shields J, Joyce M, Tyrrell DL, Oyegbami O, Elahi S. 2021. Erythroid precursors and progenitors suppress adaptive immunity and get invaded by SARS-CoV-2. Stem Cell Reports, 16(5):1165-81.

142. Bernardes JP, Mishra N, Tran F, et al. Longitudinal multi-omics analyses identify responses of megakaryocytes, erythroid cells and plasmablasts as hallmarks of severe COVID-19 trajectories. Immunity 2020; 53: 1296-1314

143. Ata F, Almasri H, Sajid J, Yousaf Z. 2020. COVID-19 presenting with diarrhoea and hyponatraemia. BMJ Case Reports CP, 13(6):e235456.

144. Khan AA, Ata F, Munir W, Yousaf Z. Fluid replacement versus fluid restriction in COVID-19 associated hyponatremia. Cureus 2020; 12 (7): e9059

145. Lippi G, South AM, Henry BM. 2020. Electrolyte imbalances in patients with severe coronavirus disease 2019 (COVID-19). Annals of clinical biochemistry, 57(3):262-5.

146. Stein PE, Badminton MN, Barth JH, Rees DC, Sarkany R, Stewart MF, Cox TM. 2012. Acute intermittent porphyria: fatal complications of treatment. Clinical Medicine, 12(3):293.

147. Zamd M, Mtioui N, Maoujoud O, Ramdani B. An unorthodox pathophysiology of severe cases of COVID-19 the weak heme hypothesis. American journal of blood research. 2020;10(6):305.

148. Stadlbauer V, Jud P, Hackl G, Reisinger AC, Eller P, Horvath A. Impact of COVID-19 on rare diseases: Report of three cases of acute hepatic porphyria affected by the pandemic. Zeitschrift für Gastroenterologie. 2021 Aug;59(08):P49.

149. Bahinipati J 2020. Correlation of urinary porphyrin and biochemical markers with the severity of symptoms of COVID19 cases. CTRI; 30-06-2020; TrialID: CTRI/2020/06/026250. Clinical Trial Register ID: ictrp-CTRI202006026250. [updated 2020 Jun 30; cited 2021 Nov 05]. Available from: http://www.ctri.nic.in/Clinicaltrials/pmaindet2.php?trialid=45057.

150. Aguilar-Galindo ÓM. About the parallels between COVID-19 and some types of porphyria. Gaceta Medica de Bilbao. 2020:100-1.

151. Batiha, G., Shaheen, H.M., Al-Kuraishy, H.M., Teibo, J.O., Akinfe, O.A., Al-Garbee, A.I., Teibo, T.K.A. and Kabrah, S.M., 2021. Possible mechanistic insights into iron homeostasis role of the action of 4-aminoquinolines (chloroquine/hydroxychloroquine) on COVID-19 (SARS-CoV-2) infection. European Review for Medical and Pharmacological Sciences, 25, pp.7565-7584.

152. Mancilha, E.M.B. \& Oliveira, J.S.R.D., 2021. SARS-CoV-2 association with hemoglobin and iron metabolism. Revista da Associação Médica Brasileira, 67, pp.1349-1352. 
153. Lappin, T.R. and Lee, F.S., 2019. Update on mutations in the HIF: EPO pathway and their role in erythrocytosis. Blood reviews, 37, p.100590.

154. Goldberg, M.A., Dunning, S.P. and Bunn, H.F., 1988. Regulation of the erythropoietin gene: evidence that the oxygen sensor is a heme protein. Science, 242(4884), pp.1412-1415.

155. Viruez-Soto, A., López-Dávalos, M.M., Rada-Barrera, G., Merino-Luna, A., Molano-Franco, D., Tinoco-Solorozano, A., Zubieta-DeUrioste, N., Zubieta-Calleja, G., Arias-Reyes, C. and Soliz, J., 2021. Low Serum Erythropoietin Levels are Associated with Fatal COVID-19 Cases at 4,150 meters above sea level. Respiratory Physiology \& Neurobiology, p.103709.

156. Yağcı, S., Serin, E., Acicbe, Ö., Zeren, M.I. and Odabaşı, M.S., 2021. The relationship between serum erythropoietin, hepcidin, and haptoglobin levels with disease severity and other biochemical values in patients with COVID-19. International Journal of Laboratory Hematology.

157. Moskvin, O.V., Kaplan, S., Gilles-Gonzalez, M.A. and Gomelsky, M., 2007. Novel heme-based oxygen sensor with a revealing evolutionary history. Journal of Biological Chemistry, 282(39), pp.28740-28748.

158. Stulbarg, M.S. and Winn, W.R., 1989. Bilateral carotid body resection for the relief of dyspnea in severe chronic obstructive pulmonary disease: physiologic and clinical observations in three patients. Chest, 95(5), pp.1123-1128.

159. Giani, L., Lovati, C., Rosa, S., Gambaro, P., De Angeli, F. and Mariani, C., 2015. Episodes of flushing, dyspnea and hypertension after carotid stenting for severe carotid stenosis. Autonomic Neuroscience, 193, pp.147-148.

160. Oguzturk, H., Karaman, E., Turtay, M.G., Gürbüz, Ş., Turgut, K., Erdogmus, Ö. and Beydilli, I., 2016. A Rare Cause of Recurrent Dyspnea in Emergency Service: Carotid Body Tumor. Journal of Advances in Medicine and Medical Research, pp.1-3.

161. Villadiego, J., Ramírez-Lorca, R., Cala, F., Labandeira-García, J.L., Esteban, M., Toledo-Aral, J.J. and López-Barneo, J., 2021. Is carotid body infection responsible for silent hypoxemia in COVID-19 patients?. Function, 2(1), p.zqaa032.

162. Porzionato, A., Emmi, A., Stocco, E., Barbon, S., Boscolo-Berto, R., Macchi, V. and De Caro, R., 2020. The potential role of the carotid body in COVID-19. American Journal of Physiology-Lung Cellular and Molecular Physiology, 319(4), pp.L620L626.

163. Machado, B.H. and Paton, J.F., 2021. Relevance of carotid bodies in COVID-19: A hypothetical viewpoint. Autonomic Neuroscience, p.102810.

164. Porzionato, A., Emmi, A., Contran, M., Stocco, E., Riccetti, S., Sinigaglia, A., Macchi, V., Barzon, L. and De Caro, R., 2021. Case Report: The Carotid Body in COVID-19: Histopathological and Virological Analyses of an Autopsy Case Series. Frontiers in immunology, p.4475.

165. Lahiri, S., Buerk, D.G., Chugh, D., Osanai, S. and Mokashi, A., 1995. Reciprocal photolabile O2 consumption and chemoreceptor excitation by carbon monoxide in the cat carotid body: evidence for cytochrome a3 as the primary $\mathrm{O} 2$ sensor. Brain research, 684(2), pp.194-200.

166. Lutz, P.L. and Prentice, H.M., 2002. Sensing and responding to hypoxia, molecular and physiological mechanisms. Integrative and Comparative Biology, 42(3), pp.463-468.

167. Kronstein-Wiedemann, R., Stadtmüller, M., Traikov, S., Georgi, M., Teichert, M., Yosef, H., Wallenborn, J., Karl, A., Schütze, K., Wagner, M. and El-Armouche, A., 2022. SARS-CoV-2 infects red blood cell progenitors and dysregulates hemoglobin and iron metabolism. Stem Cell Reviews and Reports, pp.1-13. 
Figures \& Tables

Figure 1

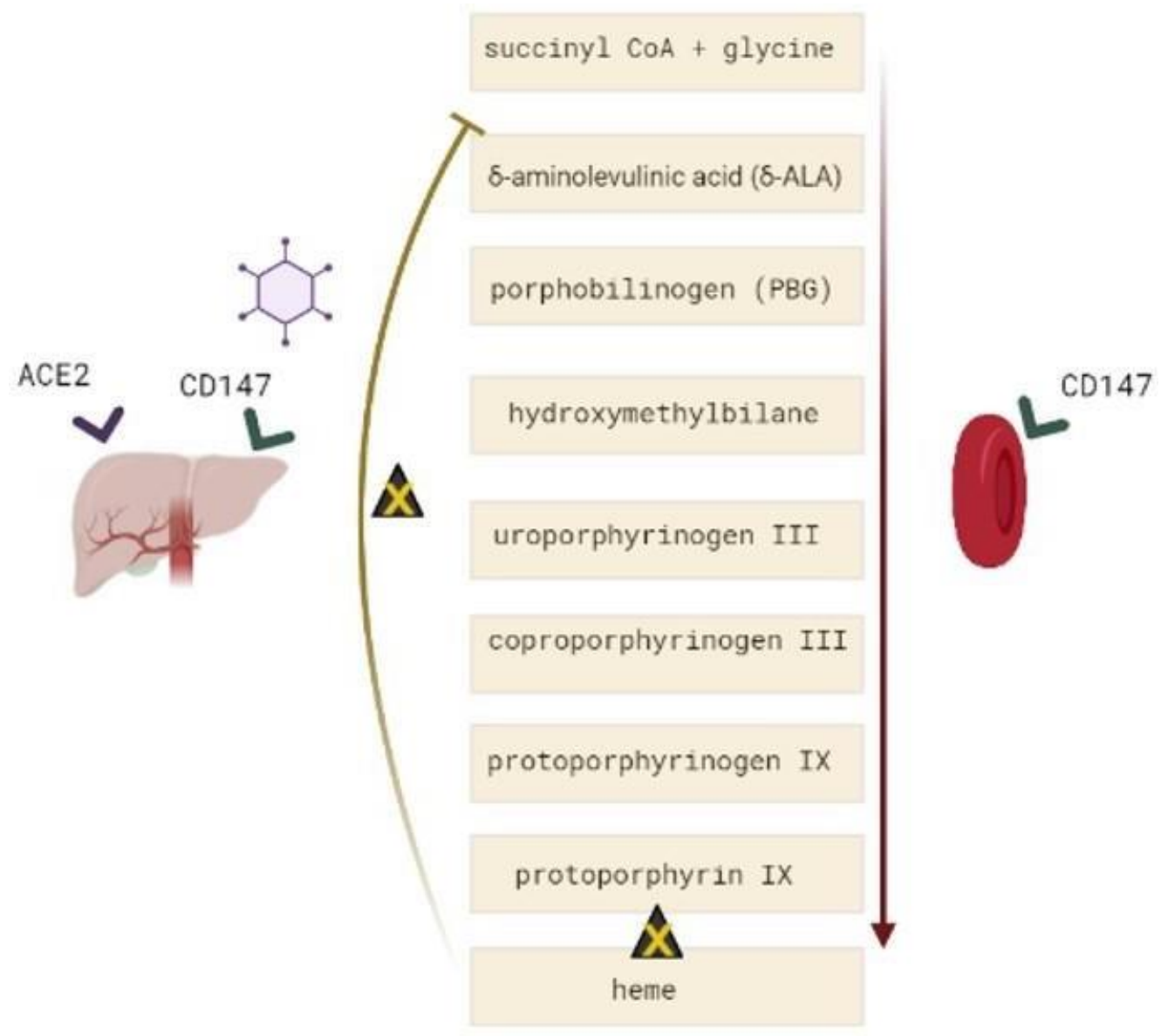




\begin{tabular}{|c|c|c|c|c|c|c|c|c|c|}
\hline Symptom & $\begin{array}{c}\text { SARS } \\
\text {-Cov- } \\
1\end{array}$ & $\begin{array}{c}\% \text { patients } \\
\text { or } \\
\text { responden } \\
\text { ts }\end{array}$ & Source & $\begin{array}{l}\text { SARS } \\
\text {-Cov- } \\
2\end{array}$ & $\begin{array}{c}\% \text { patients } \\
\text { or } \\
\text { responden } \\
\text { ts }\end{array}$ & Source & $\begin{array}{l}\text { Porphyri } \\
\qquad a\end{array}$ & $\begin{array}{c}\% \text { patients } \\
\text { or } \\
\text { responden } \\
\text { ts }\end{array}$ & Source \\
\hline Fever & Y & $\begin{array}{c}100 \% \\
100 \% \text { of } \\
138(H) \\
100 \% \text { of } 10 \\
(H) \\
100 \% \text { of } 10 \\
(H) \\
99-100 \% \\
99 \% \text { of } 144 \\
(H) \\
99 \% \text { of } 357 \\
(H) \\
91 \% \text { of } 21 \\
\text { (H) }\end{array}$ & $\begin{array}{c}\text { WHO } \\
(43) \\
\text { Lee 2003 } \\
(44) \\
\text { 44Bitnun } \\
2003 \\
\text { Hon } \\
2003 \\
(46) \\
\text { Hui 2003 } \\
(47) \\
\text { Booth } \\
2003 \\
(48) \\
\text { Yin 2018 } \\
\text { (49) } \\
\text { Chiu } \\
2003 \\
\text { (50) }\end{array}$ & Y & $\begin{array}{c}85 \% \text { of } 180 \\
(H) \\
83 \% \text { of } 99 \\
(H) \\
87 \% \text { of } 249 \\
(H) \\
77 \% \text { of } 244 \\
(H) \\
45 \% \text { of } \\
7,123(R) \\
34 \% \text { of } \\
6,452(R)\end{array}$ & $\begin{array}{l}\text { Garg } 2020 \\
(60) \\
\text { Chen N } \\
2020(13) \\
\text { Chen J } \\
2020 \text { (61) } \\
\text { Takeuchi } \\
2020 \text { (62) } \\
\text { Hopkinson } \\
2020(63) \\
\text { Menni } \\
2020(64)\end{array}$ & Y & $\begin{array}{l}\text { Isolated } \\
\text { cases }\end{array}$ & $\begin{array}{c}\text { Cohen } \\
2005(81)\end{array}$ \\
\hline Chills & Y & $\begin{array}{c}97 \% \\
73 \% \text { of } 138 \\
(H) \\
50 \% \text { of } 10 \\
(H) \\
48 \% \text { of } 21 \\
\text { (H) } \\
28 \% \text { of } 144 \\
\text { (H) } \\
15-73 \% \\
10 \% \text { of } 10 \\
\text { (H) }\end{array}$ & $\begin{array}{c}\text { WHO } \\
(43) \\
\text { Lee } 2003 \\
(44) \\
\text { Hon } \\
2003 \\
(46) \\
\text { Chiu } \\
2003 \\
\text { (50) } \\
\text { Booth } \\
2003 \\
\text { (48) } \\
\text { Hui 2003 } \\
\text { (47) } \\
\text { 44Bitnun } \\
2003\end{array}$ & $Y$ & $\begin{array}{c}46 \% \text { of } 251 \\
(\mathrm{H}) \\
85 \% \text { of } 180 \\
\text { (H) }\end{array}$ & $\begin{array}{c}\text { Campioli } \\
2020 \\
(37) \\
\text { Garg } 2020 \\
(60)\end{array}$ & $\mathrm{N}$ & $\begin{array}{c}\text { Not } \\
\text { applicable }\end{array}$ & $\begin{array}{c}\text { Not } \\
\text { applicable }\end{array}$ \\
\hline Myalgia & $Y$ & $\begin{array}{c}81 \% \\
61 \% \text { of } 138 \\
(H) \\
59 \% \text { of } 357 \\
(H) \\
49 \% \text { of } 144 \\
(H) \\
45-61 \% \\
40 \% \text { of } 10 \\
\text { (H) } \\
10 \% \text { of } 21 \\
\text { (H) }\end{array}$ & $\begin{array}{c}\text { WHO } \\
(43) \\
\text { Lee } 2003 \\
(44) \\
\text { Yin } 2018 \\
\text { (49) } \\
\text { Booth } \\
2003 \\
(48) \\
\text { Hui 2003 } \\
(47) \\
\text { Hon } \\
2003 \\
(46) \\
\text { Chiu } \\
2003 \\
\text { (50) }\end{array}$ & $Y$ & $\begin{array}{c}34 \% \text { of } \\
7,123(\mathrm{R}) \\
34 \% \text { of } 180 \\
(\mathrm{H}) \\
11 \% \text { of } 99 \\
\text { (H) }\end{array}$ & $\begin{array}{c}\text { Garg } 2020 \\
(60) \\
\text { Chen N } \\
2020 \\
(13)\end{array}$ & $Y$ & $\begin{array}{c}30 \% \text { of } 149 \\
(\mathrm{H})\end{array}$ & $\begin{array}{c}\text { Bylesjö } \\
2009(82)\end{array}$ \\
\hline Persistent cough & Y & $\begin{array}{c}80 \% \text { of } 10 \\
(H) \\
75 \% \text { of } 144\end{array}$ & $\begin{array}{l}\text { Hon } \\
2003 \\
(46)\end{array}$ & Y & $\begin{array}{c}86 \% \text { of } 180 \\
(H) \\
82 \% \text { of } 99\end{array}$ & $\begin{array}{l}\text { Garg } 2020 \\
(60)\end{array}$ & Y & $\begin{array}{l}\text { Isolated } \\
\text { cases }\end{array}$ & $\begin{array}{l}\text { Quansah } \\
2014 \text { (83) }\end{array}$ \\
\hline
\end{tabular}




\begin{tabular}{|c|c|c|c|c|c|c|c|c|c|}
\hline & & $\begin{array}{c}(\mathrm{H}) \\
60 \% \text { of } 10 \\
(\mathrm{H}) \\
58 \% \text { of } 357 \\
(\mathrm{H}) \\
57-75 \% \\
50 \% \text { of } 138 \\
(\mathrm{H}) \\
43 \% \text { of } 21 \\
(\mathrm{H}) \\
39 \%\end{array}$ & $\begin{array}{c}\text { Booth } \\
2003 \\
\text { (48) } \\
\text { 44Bitnun } \\
2003 \\
\text { Yin } 2018 \\
\text { (49) } \\
\text { Hui 2003 } \\
\text { (47) } \\
\text { Lee 2003 } \\
\text { (44) } \\
\text { Chiu } \\
2003 \\
\text { (50) } \\
\text { WHO } \\
\text { (43) } \\
2003\end{array}$ & & $\begin{array}{c}(\mathrm{H}) \\
87 \% \text { of } \\
7,123(\mathrm{R}) \\
57 \% \text { of } \\
6,452(\mathrm{R}) \\
44 \% \text { of } \\
244(\mathrm{H}) \\
37 \% \text { of } \\
249(\mathrm{H})\end{array}$ & $\begin{array}{c}\text { Chen N } \\
2020 \\
(13) \\
\text { Hopkinson } \\
2020(63) \\
\text { Menni } \\
2020 \text { (64) } \\
\text { Takeuchi } \\
2020 \text { (62) } \\
\text { Chen J } \\
2020(61)\end{array}$ & & & \\
\hline Sore throat & $y$ & $\begin{array}{c}30 \% \\
13-25 \% \\
23 \% \\
17 \% \text { of } 357 \\
(H) \\
13 \% \text { of } 144 \\
\text { (H) } \\
10 \% \text { of } 10 \\
\text { (H) } \\
5 \% \text { of } 21 \\
\text { (H) }\end{array}$ & $\begin{array}{c}\text { Hon } \\
2003 \\
(46) \\
\text { Hui 2003 } \\
\text { (47) } \\
\text { WHO } \\
\text { (43) } \\
\text { Yin 2018 } \\
\text { (49) } \\
\text { Booth } \\
2003 \\
\text { (48) } \\
44 \text { Bitnun } \\
2003 \\
\text { Chiu } \\
2003 \\
\text { (50) }\end{array}$ & $Y$ & $\begin{array}{c}45 \% \text { of } \\
7,123(\mathrm{R}) \\
18 \% \text { of } 180 \\
(\mathrm{H}) \\
12 \% \text { of } 244 \\
\text { (H) } \\
5 \% \text { of } 99 \\
\text { (H) } \\
6 \% \text { of } 249 \\
\text { (H) }\end{array}$ & $\begin{array}{c}\text { Hopkinson } \\
2020(63) \\
\text { Garg } 2020 \\
(60) \\
\text { Takeuchi } \\
2020(62) \\
\text { Chen N } \\
2020(13) \\
\text { Chen J } \\
2020(61)\end{array}$ & $\mathrm{N}$ & $\begin{array}{c}\text { Not } \\
\text { applicable }\end{array}$ & $\begin{array}{c}\text { Not } \\
\text { applicable }\end{array}$ \\
\hline Abdominal pain & $Y$ & $\begin{array}{c}10 \% \text { of } 10 \\
(H) \\
4 \% \text { of } 144 \\
\text { (H) }\end{array}$ & $\begin{array}{c}\text { Hon } \\
2003 \\
(46) \\
\text { Booth } \\
2003 \\
(48)\end{array}$ & $Y$ & $\begin{array}{c}30 \% \text { of } \\
7,123(\mathrm{R}) \\
21 \% \text { of } \\
6,452(\mathrm{R}) \\
8 \% \text { of } 180 \\
\text { (H) } \\
1 \% \text { of } 204 \\
\text { (H) }\end{array}$ & $\begin{array}{c}\text { Hopkinson } \\
2020(63) \\
\text { Menni } \\
2020(64) \\
\text { Garg 2020 } \\
(60) \\
\text { Pan 2020 } \\
(65)\end{array}$ & $Y$ & $\begin{array}{c}100 \% \text { of } \\
102(H) \\
99 \% \text { of } 91 \\
(R) \\
94 \% \text { of } 50 \\
\text { (H) } \\
86 \% \text { of } 149 \\
\text { (H) }\end{array}$ & $\begin{array}{c}\text { De Siervi } \\
\text { 1999 (84) } \\
\text { Andersso } \\
\text { n } 2003 \\
\text { (85) } \\
\text { Yang 2019 } \\
\text { (86) } \\
\text { Bylesjö } \\
2009 \text { (82) }\end{array}$ \\
\hline Diarrhoea & $Y$ & $\begin{array}{c}8 \% \text { of } \\
1,291(\mathrm{H}) \\
20-25 \% \\
24 \% \text { of } 144 \\
(\mathrm{H}) \\
17 \% \text { of } 357 \\
(\mathrm{H}) \\
10-20 \%(\mathrm{H}) \\
10 \% \text { of } 21 \\
(\mathrm{H}) \\
10 \% \text { of } 10 \\
\text { (H) }\end{array}$ & $\begin{array}{c}\text { Lai } 2004 \\
(51) \\
\text { Hui 2003 } \\
(47) \\
\text { Booth } \\
2003 \\
(48) \\
\text { Yin 2018 } \\
(49) \\
\text { WHO } \\
\text { Chiu } \\
2003 \\
\text { (50) } \\
44 \text { Bitnun } \\
2003\end{array}$ & $Y$ & $\begin{array}{c}38 \% \text { of } \\
7,123(\mathrm{R}) \\
27 \% \text { of } 180 \\
(\mathrm{H}) \\
26 \% \text { of } \\
6,452(\mathrm{R}) \\
17 \% \text { of } \\
204(\mathrm{H}) \\
3 \% \text { of } 249 \\
\text { (H) } \\
1 \% \text { of } 244 \\
\text { (H) }\end{array}$ & $\begin{array}{c}\text { Hopkinson } \\
2020(63) \\
\text { Garg } 2020 \\
(60) \\
\text { Menni } \\
2020(64) \\
\text { Pan } 2020 \\
(65) \\
\text { Chen J } \\
2020 \text { (61) } \\
\text { Takeuchi } \\
2020 \text { (62) }\end{array}$ & $Y$ & Typical & $\begin{array}{c}\text { Kauppine } \\
\text { n } 2005 \\
\text { (87) }\end{array}$ \\
\hline $\begin{array}{l}\text { Nausea \& } \\
\text { vomiting }\end{array}$ & $Y$ & $\begin{array}{c}20-35 \% \\
20 \% \text { of } 10 \\
(H) \\
20 \% \text { of } 10\end{array}$ & $\begin{array}{l}\text { Hui } 2003 \\
\text { (47) } \\
\text { Hon } \\
2003\end{array}$ & $Y$ & $\begin{array}{c}24 \% \text { of } 180 \\
(H) \\
1 \% \text { of } 99 \\
(H)\end{array}$ & $\begin{array}{c}\text { Chen N } \\
2020 \\
(13)\end{array}$ & $\mathrm{Y}$ & $\begin{array}{c}72 \% \text { of } 50 \\
(H) \\
51 \% \text { of } 91 \\
(R)\end{array}$ & $\begin{array}{l}\text { Yang } 2019 \\
\quad(86) \\
\text { Andersso } \\
\text { n } 2003\end{array}$ \\
\hline
\end{tabular}




\begin{tabular}{|c|c|c|c|c|c|c|c|c|c|}
\hline & & $\begin{array}{c}(\mathrm{H}) \\
19 \% \text { of } 144 \\
(\mathrm{H}) \\
15 \% \text { of } 357 \\
\text { (H) }\end{array}$ & $\begin{array}{c}(46) \\
44 \text { Bitnun } \\
2003 \\
\text { Booth } \\
2003 \\
(48) \\
\text { Yin 2018 } \\
(49)\end{array}$ & & & & & $\begin{array}{c}36 \% \text { of } 149 \\
(H) \\
11 \% \text { of } 102 \\
\text { (H) }\end{array}$ & $\begin{array}{c}(85) \\
\text { Bylesjö } \\
2009(82) \\
\text { De Siervi } \\
1999(84)\end{array}$ \\
\hline Constipation & $Y$ & $\begin{array}{l}\text { Isolated } \\
\text { cases }\end{array}$ & $\begin{array}{l}\text { Lin } 2003 \\
(52) \\
\text { Jin-Pan } \\
2003 \\
(53)\end{array}$ & $\mathrm{Y}$ & $\begin{array}{l}\text { Isolated } \\
\text { cases }\end{array}$ & $\begin{array}{c}\text { Chow } \\
2020(66) \\
\text { Alvarez- } \\
\text { Troncoso } \\
2020(67)\end{array}$ & $Y$ & $\begin{array}{c}57 \% \text { of } 91 \\
\text { (R) } \\
42 \% \text { of } 50 \\
\text { (H) } \\
41 \% \text { of } 149 \\
\text { (H) } \\
37 \% \text { of } 102 \\
\text { (H) }\end{array}$ & $\begin{array}{c}\text { Andersso } \\
\text { n 2003 } \\
(85) \\
\text { Yang 2019 } \\
\text { (86) } \\
\text { Bylesjö } \\
2009 \text { (82) } \\
\text { De Siervi } \\
\text { 1999 (84) }\end{array}$ \\
\hline Anorexia & & $\begin{array}{c}57 \% \text { of } 21 \\
(H)\end{array}$ & $\begin{array}{l}\text { Chiu } \\
2003 \\
(50)\end{array}$ & $\mathrm{Y}$ & $\begin{array}{c}50 \% \text { of } \\
7,123(\mathrm{R}) \\
42 \% \text { of } \\
6,452(\mathrm{R}) \\
40 \% \text { of } 204 \\
\text { (H) } \\
3 \% \text { of } 249 \\
\text { (H) }\end{array}$ & $\begin{array}{c}\text { Hopkinson } \\
2020(63) \\
\text { Menni } \\
2020(64) \\
\text { Pan } 2020 \\
(65) \\
\text { Chen J } \\
2020(61)\end{array}$ & $\mathrm{Y}$ & $\begin{array}{c}37 \% \text { of } 102 \\
\text { (H) }\end{array}$ & $\begin{array}{c}\text { De Siervi } \\
1999(84)\end{array}$ \\
\hline Headache & $\mathrm{Y}$ & $\begin{array}{c}84 \% \\
20-56 \% \\
50 \% \text { of } 138 \\
\text { (H) } \\
39 \% \text { of } 357 \\
\text { (H) } \\
35 \% \text { of } 144 \\
\text { (H) } \\
40 \% \text { of } 10 \\
\text { (H) } \\
14 \% \text { of } 21 \\
\text { (H) } \\
10 \% \text { of } 10 \\
\text { (H) }\end{array}$ & $\begin{array}{c}\text { WHO } \\
(43) \\
\text { Hui 2003 } \\
(47) \\
\text { Lee 2003 } \\
(44) \\
\text { Yin 2018 } \\
(49) \\
\text { Booth } \\
2003 \\
(48) \\
\text { Hon } \\
2003 \\
(46) \\
\text { Chiu } \\
2003 \\
\text { (50) } \\
\text { Bitnun } \\
2003 \\
\text { (45) }\end{array}$ & $\mathrm{Y}$ & $\begin{array}{c}68 \% \text { of } \\
7,123(\mathrm{R}) \\
16 \% \text { of } 180 \\
\text { (H) } \\
8 \% \text { of } 99 \\
\text { (H) } \\
11 \% \text { of } 249 \\
\text { (H) } \\
3 \% \text { of } 244 \\
\text { (H) }\end{array}$ & $\begin{array}{c}\text { Hopkinson } \\
2020(63) \\
\text { Garg } 2020 \\
(60) \\
\text { Chen N } \\
2020(13) \\
\text { Chen J } \\
2020(61) \\
\text { Takeuchi } \\
2020(62)\end{array}$ & $\mathrm{Y}$ & $\begin{array}{c}13 \% \text { of } 149 \\
\text { (H) }\end{array}$ & $\begin{array}{c}\text { Bylesjö } \\
2009(82)\end{array}$ \\
\hline Dizziness & $Y$ & $\begin{array}{c}4-43 \% \\
61 \% \\
38 \% \text { of } 21 \\
\text { (H) } \\
10 \% \text { of } 10 \\
\text { (H) } \\
4 \% \text { of } 144 \\
\text { (H) }\end{array}$ & $\begin{array}{c}\text { Hui } 2003 \\
(47) \\
\text { WHO } \\
(43) \\
\text { Hon } \\
2003 \\
(46) \\
\text { Booth } \\
2003 \\
(48)\end{array}$ & $\mathrm{Y}$ & $\begin{array}{c}2 \% \text { of } 141 \\
\text { (M) } \\
11 \% \text { of } 249 \\
\text { (H) }\end{array}$ & $\begin{array}{c}\text { Saniasiaya } \\
2020(68) \\
\text { Chen J } \\
2020(61)\end{array}$ & $Y$ & $\begin{array}{l}\text { Isolated } \\
\text { cases }\end{array}$ & $\begin{array}{c}\text { Solinas } \\
2008(88)\end{array}$ \\
\hline Neuropsychiatric & $Y$ & $\begin{array}{l}\text { Isolated } \\
\text { cases }\end{array}$ & $\begin{array}{c}\text { Sheng } \\
2005 \\
(54) \\
\text { Hui } 2009 \\
\text { (55) }\end{array}$ & $\mathrm{Y}$ & $\begin{array}{c}25 \% \text { of } \\
7,123(\mathrm{R}) \\
18 \% \text { of } \\
6,452(\mathrm{R}) \\
6 \% \text { of } 180 \\
\text { (H) }\end{array}$ & $\begin{array}{c}\text { Hopkinson } \\
2020(63) \\
\text { Menni } \\
2020(64) \\
\text { Garg 2020 } \\
(60)\end{array}$ & $Y$ & $\begin{array}{c}72 \% \text { of } 50 \\
(H) \\
59 \% \text { of } 91 \\
\text { (R) } \\
29 \% \text { of } 149 \\
\text { (H) }\end{array}$ & $\begin{array}{l}\text { Yang } 2019 \\
(86) \\
\text { Andersso } \\
\text { n } 2003 \\
(85) \\
\text { Bylesjö } \\
2009(82)\end{array}$ \\
\hline
\end{tabular}




\begin{tabular}{|c|c|c|c|c|c|c|c|c|c|}
\hline & & & & & & & & $\begin{array}{c}18 \% \text { of } 102 \\
\text { (H) }\end{array}$ & $\begin{array}{l}\text { De Siervi } \\
1999(84)\end{array}$ \\
\hline Paralysis & $\mathrm{N}$ & $\begin{array}{c}\text { Not } \\
\text { applicable }\end{array}$ & $\begin{array}{c}\text { Not } \\
\text { applicabl } \\
\text { e }\end{array}$ & $Y$ & $\begin{array}{l}\text { Isolated } \\
\text { cases }\end{array}$ & $\begin{array}{c}\text { Maurier } \\
2020 \text { (69) } \\
\text { Figueiredo } \\
2020 \text { (70) } \\
\text { Casas 2020 } \\
\text { (71) }\end{array}$ & $Y$ & $\begin{array}{c}20 \% \text { of } 149 \\
\text { (H) }\end{array}$ & $\begin{array}{c}\text { Bylesjö } \\
2009(82)\end{array}$ \\
\hline Dyspnea & $Y$ & $\begin{array}{c}42 \% \text { of } 144 \\
(H) \\
14 \% \text { of } 21 \\
(H) \\
40-42 \% \\
27 \% \text { of } 357 \\
\text { (H) } \\
10 \% \text { of } 10 \\
\text { (H) }\end{array}$ & $\begin{array}{c}\text { Booth } \\
2003 \\
(48) \\
\text { Chiu } \\
2003 \\
(50) \\
\text { Hui 2003 } \\
\text { (47) } \\
\text { Yin 2018 } \\
\text { (49) } \\
\text { Bitnun } \\
2003 \\
\text { (45) }\end{array}$ & $Y$ & $\begin{array}{c}80 \% \text { of } 180 \\
(H) \\
60 \% \text { of } \\
7,123(R) \\
31 \% \text { of } 99 \\
(H) \\
15 \% \text { of } \\
6,452(R) \\
8 \% \text { of } 249 \\
(H) \\
8 \% \text { of } 244 \\
(H)\end{array}$ & $\begin{array}{c}\text { Garg } 2020 \\
(60) \\
\text { Hopkinson } \\
2020(63) \\
\text { Chen N } \\
2020 \\
(13) \\
\text { Menni } \\
2020(64) \\
\text { Chen J } \\
2020(61) \\
\text { Takeuchi } \\
2020(62)\end{array}$ & $Y$ & $\begin{array}{l}\text { Isolated } \\
\text { cases }\end{array}$ & $\begin{array}{c}\text { Kauppine } \\
\text { n } 2005 \\
\text { (87) }\end{array}$ \\
\hline ARDS & $Y$ & $\begin{array}{l}10-20 \% \\
13-26 \%\end{array}$ & $\begin{array}{c}\text { WHO } \\
\text { (43) } \\
\text { Lau 2004 } \\
(56)\end{array}$ & $Y$ & $\begin{array}{c}17 \% \text { of } 99 \\
(H)\end{array}$ & $\begin{array}{c}\text { Chen N } \\
2020 \\
(13)\end{array}$ & $\mathrm{Y}$ & $\begin{array}{l}\text { Isolated } \\
\text { cases }\end{array}$ & $\begin{array}{c}\text { Kauppine } \\
\text { n } 2005 \\
(87)\end{array}$ \\
\hline Septic shock & $Y$ & $15 \%$ & $\begin{array}{l}\text { Lau } 2004 \\
\quad(56)\end{array}$ & $Y$ & $\begin{array}{c}4 \% \text { of } 99 \\
\text { (H) }\end{array}$ & $\begin{array}{c}\text { Chen N } \\
2020 \\
(13)\end{array}$ & $\mathrm{N}$ & $\begin{array}{c}\text { Not } \\
\text { applicable }\end{array}$ & $\begin{array}{c}\text { Not } \\
\text { applicable }\end{array}$ \\
\hline $\begin{array}{l}\text { Multiple organ } \\
\text { dysfunction }\end{array}$ & $Y$ & $15 \%$ & $\begin{array}{l}\text { Lau } 2004 \\
\quad(56)\end{array}$ & $\mathrm{Y}$ & $\begin{array}{c}12 \% \text { of } 249 \\
\text { (H) }\end{array}$ & $\begin{array}{c}\text { Chen J } \\
2020(61)\end{array}$ & $\mathrm{N}$ & $\begin{array}{c}\text { Not } \\
\text { applicable }\end{array}$ & $\begin{array}{c}\text { Not } \\
\text { applicable }\end{array}$ \\
\hline Pneumonia & $Y$ & $\begin{array}{c}17 \% \text { of } 357 \\
\text { (H) }\end{array}$ & $\begin{array}{l}\text { Yin } 2018 \\
(49)\end{array}$ & $Y$ & $\begin{array}{c}36 \% \text { of } 244 \\
\text { (H) } \\
1 \% \text { of } 99 \\
\text { (H) }\end{array}$ & $\begin{array}{l}\text { Takeuchi } \\
2020(62) \\
\text { Chen N } \\
2020 \\
(13)\end{array}$ & $Y$ & $\begin{array}{l}\text { Isolated } \\
\text { cases }\end{array}$ & $\begin{array}{c}\text { Kauppine } \\
\text { n } 2005 \\
\text { (87) }\end{array}$ \\
\hline Thrombosis & $Y$ & $\begin{array}{c}50 \% \text { of } 8 \\
(\mathrm{H}) \\
3 \% \text { of } 153 \\
\text { (H) }\end{array}$ & $\begin{array}{c}\text { Chong } \\
2004 \\
(57) \\
\text { Wong } \\
2003 \\
(58)\end{array}$ & $Y$ & $\begin{array}{c}16 \% \text { of } \\
3,334(H)\end{array}$ & $\begin{array}{l}\text { Bilaloglu } \\
2020(72)\end{array}$ & $\mathrm{Y}$ & $\begin{array}{l}\text { Isolated } \\
\text { cases }\end{array}$ & $\begin{array}{l}\text { Dowman } \\
2012(89)\end{array}$ \\
\hline $\begin{array}{c}\text { Tachycardia* } \\
\text { arrhythmia }\end{array}$ & $Y$ & $\begin{array}{c}72 \% \text { of } 121 \\
\text { (H) } \\
46 \% \text { of } 144 \\
\text { (H) }\end{array}$ & $\begin{array}{c}\text { Yu } 2006 \\
\text { (59) } \\
\text { Booth } \\
2003 \\
(48)\end{array}$ & $Y$ & $\begin{array}{c}16.7 \% \text { of } \\
138(\mathrm{H}) \\
\text { Isolated } \\
\text { cases }\end{array}$ & $\begin{array}{c}\text { Wang } \\
2020(73) \\
\text { Miglis } \\
2020(74) \\
\text { Umapathi } \\
2020 \text { (75) } \\
\text { Mitacchio } \\
\text { ne } 2020 \\
\text { (76) } \\
\text { Babapoor- } \\
\text { Farrokhran } \\
2020(77) \\
\text { Reddy } \\
2020(78)\end{array}$ & $Y$ & $\begin{array}{c}30 \% \text { of } 102 \\
\text { (H) } \\
10 \% \text { of } 149 \\
\text { (H) }\end{array}$ & $\begin{array}{c}\text { De Siervi } \\
1999(84) \\
\text { Bylesjö } \\
2009(82)\end{array}$ \\
\hline Chest pain & $Y$ & $\begin{array}{c}10 \% \text { of } 144 \\
\text { (H) }\end{array}$ & $\begin{array}{c}\text { Booth } \\
2003 \\
(48)\end{array}$ & $Y$ & $\begin{array}{c}50 \% \text { of } \\
7,123(\mathrm{R}) \\
43 \% \text { of } \\
6,452(\mathrm{R}) \\
15 \% \text { of } \\
180(\mathrm{H})\end{array}$ & $\begin{array}{c}\text { Hopkinson } \\
2020(63) \\
\text { Menni } \\
2020(64) \\
\text { Garg } 2020 \\
\text { (60) }\end{array}$ & $Y$ & $50-52 \%(H)$ & $\begin{array}{l}\text { Sassa } \\
2006\end{array}$ \\
\hline
\end{tabular}




\begin{tabular}{|c|c|c|c|c|c|c|c|c|c|}
\hline & & & & & $\begin{array}{c}2 \% \text { of } 99 \\
(H)\end{array}$ & $\begin{array}{c}\text { Chen N } \\
2020 \\
(13)\end{array}$ & & & \\
\hline $\begin{array}{c}\text { Anosmia* } \\
\text { sensory loss }\end{array}$ & $\mathrm{N}$ & $\begin{array}{c}\text { Not } \\
\text { applicable }\end{array}$ & $\begin{array}{c}\text { Not } \\
\text { applicabl } \\
\text { e }\end{array}$ & $Y$ & $\begin{array}{c}68 \% \text { of } \\
7,123(R) \\
65 \% \text { of } \\
6,452(R)\end{array}$ & $\begin{array}{c}\text { Hopkinson } \\
2020(63) \\
\text { Menni } \\
2020(64)\end{array}$ & $Y$ & $\begin{array}{c}7 \% \text { of } 149 \\
\text { (H) } \\
17 \% \text { of } 91 \\
\text { (R) }\end{array}$ & $\begin{array}{c}\text { Bylesjö } \\
2009 \text { (82) } \\
\text { Anderssso } \\
\text { n } 2003\end{array}$ \\
\hline $\begin{array}{c}\text { Ageusia* } \\
\text { sensory loss }\end{array}$ & $\mathrm{N}$ & $\begin{array}{c}\text { Not } \\
\text { applicable }\end{array}$ & $\begin{array}{c}\text { Not } \\
\text { applicabl } \\
\text { e }\end{array}$ & $Y$ & $\begin{array}{c}65 \% \text { of } \\
6,452(R)\end{array}$ & $\begin{array}{c}\text { Menni } \\
2020 \\
(64)\end{array}$ & $Y$ & $\begin{array}{c}7 \% \text { of } 149 \\
\text { (H) }\end{array}$ & $\begin{array}{c}\text { Bylesjö } \\
2009(82)\end{array}$ \\
\hline $\begin{array}{c}\text { Hyperinflammat } \\
\text { ory } \\
\text { syndrome }\end{array}$ & $\mathrm{N}$ & $\begin{array}{c}\text { Not } \\
\text { applicable }\end{array}$ & $\begin{array}{c}\text { Not } \\
\text { applicabl } \\
\text { e }\end{array}$ & $Y$ & $\begin{array}{l}\text { Isolated } \\
\text { cases }\end{array}$ & $\begin{array}{l}\text { Riphagen } \\
2020 \text { (79) }\end{array}$ & $N$ & $\begin{array}{c}\text { Not } \\
\text { applicable }\end{array}$ & $\begin{array}{c}\text { Not } \\
\text { applicable }\end{array}$ \\
\hline $\begin{array}{c}\text { Rash* } \\
\text { skin lesions }\end{array}$ & $Y$ & $\begin{array}{c}5 \% \text { of } 21 \\
\text { (H) }\end{array}$ & $\begin{array}{l}\text { Chiu } \\
2003 \\
(50)\end{array}$ & $Y$ & $\begin{array}{l}\text { Isolated } \\
\text { cases }\end{array}$ & $\begin{array}{c}\text { Hay } 2020 \\
(80)\end{array}$ & $Y$ & Typical & $\begin{array}{l}\text { Andersen } \\
2014(90)\end{array}$ \\
\hline
\end{tabular}


Figure 2

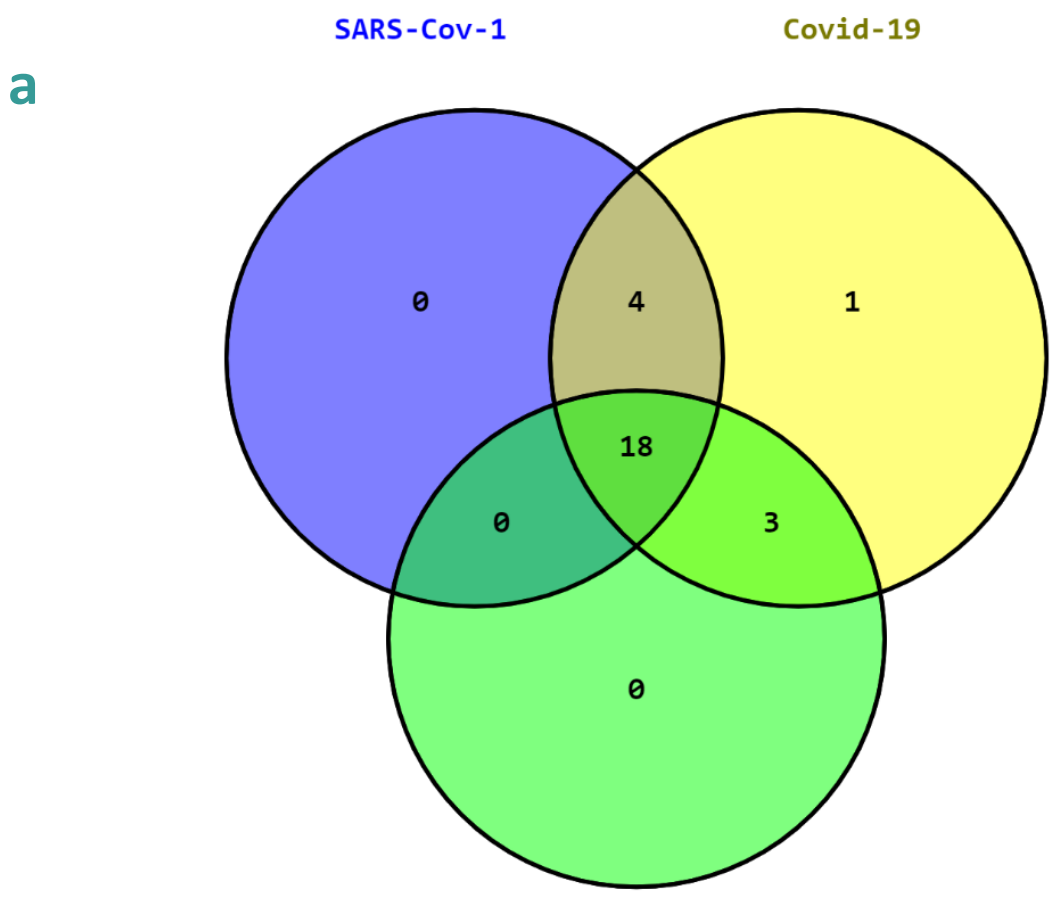

Porphyria

b

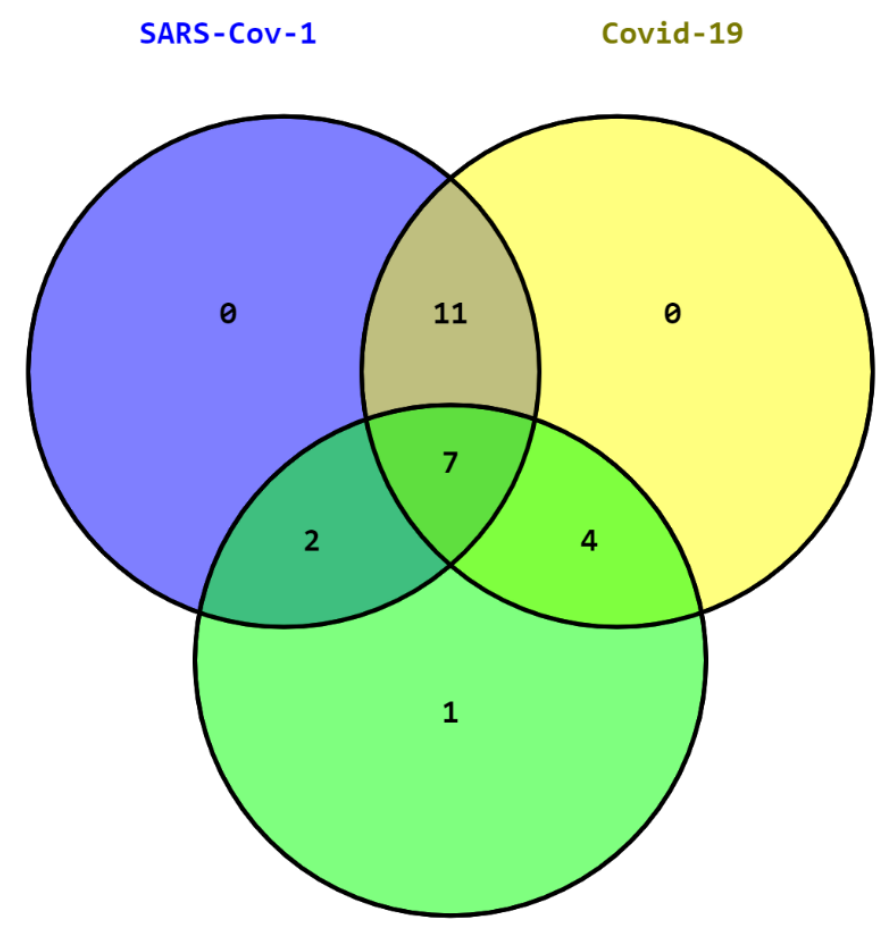

Porphyria 
Table 1

\begin{tabular}{|c|c|c|c|c|c|c|c|c|c|}
\hline Species & $\begin{array}{l}\text { Biological } \\
\text { importance }\end{array}$ & $\begin{array}{l}\text { Cellular } \\
\text { compartm } \\
\text { ent of } \\
\text { blood in } \\
\text { acute } \\
\text { porphyria }\end{array}$ & $\begin{array}{l}\text { Cellular } \\
\text { compartm } \\
\text { ent of } \\
\text { blood in } \\
\text { Covid-19 }\end{array}$ & $\begin{array}{l}\text { Plasma in } \\
\text { acute } \\
\text { porphyria }\end{array}$ & $\begin{array}{l}\text { Serum } \\
\text { in } \\
\text { Covid- } \\
19\end{array}$ & $\begin{array}{c}\text { Urine in acute } \\
\text { porphyria }\end{array}$ & $\begin{array}{l}\text { Urine } \\
\text { in } \\
\text { Covid- } \\
19\end{array}$ & $\begin{array}{l}\text { Fecal } \\
\text { porphyrins } \\
\text { In acute } \\
\text { porphyria }\end{array}$ & $\begin{array}{c}\text { Fecal } \\
\text { porphyri } \\
\text { ns in } \\
\text { Covid-19 }\end{array}$ \\
\hline Total porphyrins & $\begin{array}{c}\text { Porphyrinuria may } \\
\text { indicate clinical } \\
\text { porphyria }\end{array}$ & $\begin{array}{l}\text { Normal or } \\
\text { slightly } \\
\text { elevated } \\
\text { erythrocyte } \\
\text { porphyrins } \\
\text { (VP and } \\
\text { HCP) }\end{array}$ & $\downarrow$ & $\begin{array}{l}\text { Markedly } \uparrow \\
\text { with } \\
\text { fluorescence } \\
\text { peak at } \sim 626 \mathrm{~nm} \\
\text { (VP) }\end{array}$ & $\begin{array}{c}\text { unknow } \\
n\end{array}$ & $\begin{array}{c}\uparrow_{\text {mostly }} \\
\text { uroporphyrin } \\
\text { and } \\
\begin{array}{c}\text { coproporphyrin } \\
\text { (AIP, HCP, VP) }\end{array} \\
\uparrow_{\text {mostly }} \\
\text { coproporphyrin } \\
\text { III (ADP) }\end{array}$ & $\begin{array}{l}\text { unkno } \\
\text { wn }\end{array}$ & 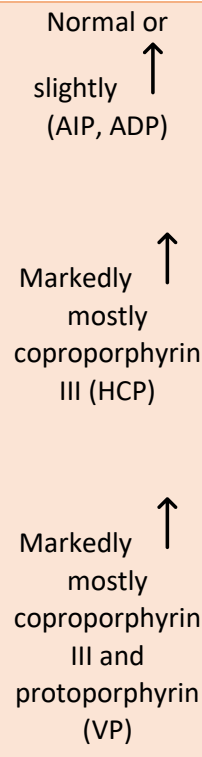 & unknown \\
\hline $\begin{array}{l}\text { Uroporphyrinoge } \\
n \text { III }\end{array}$ & $\begin{array}{c}\text { An intermediate in } \\
\text { the heme } \\
\text { biosynthetic } \\
\text { pathway, follows } \\
\text { hydroxymethylbilan } \\
\text { e and precedes } \\
\text { coproporphyrinoge } \\
\text { n III }\end{array}$ & $\begin{array}{l}\text { Decreased } \\
\text { in non- } \\
\text { acute } \\
\text { porphyria } \\
\text { (CEP) }\end{array}$ & $\uparrow$ & --- & --- & --- & --- & --- & --- \\
\hline $\begin{array}{l}\text { Uroporphyrin I } \\
\text { (URO I) }\end{array}$ & $\begin{array}{c}\text { Porphyrin } \\
\text { metabolite derived } \\
\text { from } \\
\text { uroporphyrinogen }\end{array}$ & $\begin{array}{c}\text { Increased in } \\
\text { non-acute } \\
\text { CEP }\end{array}$ & $\uparrow$ & $\begin{array}{c}\uparrow_{\text {in AIP and }} \\
\text { non-acute PCT }\end{array}$ & $\uparrow$ & $\uparrow_{\substack{(\mathrm{AIP}, \mathrm{HCP} \\
\mathrm{VP})}}$ & $\begin{array}{c}\text { unkno } \\
\text { wn }\end{array}$ & $\begin{array}{l}\text { Increased in } \\
\text { non-acute CEP } \\
\text { [Resource V, }\end{array}$ & unknown \\
\hline $\begin{array}{l}\text { Coproporphyrino } \\
\text { gen III }\end{array}$ & $\begin{array}{c}\text { An intermediate in } \\
\text { the heme } \\
\text { biosynthetic } \\
\text { pathway, follows } \\
\text { uroporphyrinogen } \\
\text { III and precedes } \\
\text { protoporphyrinoge } \\
\text { n III }\end{array}$ & unknownt & $\downarrow$ & unknownt & $\begin{array}{c}\text { unknow } \\
n\end{array}$ & $\uparrow_{\text {in } \mathrm{HCP}}$ & $\begin{array}{l}\text { unkno } \\
\text { wn }\end{array}$ & $\uparrow_{\text {in } \mathrm{HCP}}$ & unknown \\
\hline $\begin{array}{l}\text { Coproporphyrin I } \\
\text { (COPI) }\end{array}$ & $\begin{array}{c}\text { Porphyrin } \\
\text { metabolite derived } \\
\text { from } \\
\text { coproporphyrinoge } \\
\mathrm{n}\end{array}$ & $\begin{array}{c}\text { Increased in } \\
\text { non-acute } \\
\text { CEP }\end{array}$ & $\downarrow$ & $\begin{array}{l}\text { normal or } \uparrow \\
\text { in AIP, EPP and } \\
\text { PCT }\end{array}$ & $\uparrow$ & $\uparrow_{\substack{(A I P, H C P \\
V P)}}$ & $\begin{array}{l}\text { unkno } \\
\text { wn }\end{array}$ & $\begin{array}{c}\text { Increased } \\
\text { in non-acute } \\
\text { CEP }\end{array}$ & unknown \\
\hline $\begin{array}{l}\text { Coproporphyrin III } \\
\text { (COP III) }\end{array}$ & $\begin{array}{c}\text { Porphyrin } \\
\text { metabolite arising } \\
\text { from heme } \\
\text { biosynthesis }\end{array}$ & unknownt & Normal & $\begin{array}{l}\text { normal or } \uparrow \\
\text { in AIP, EPP and } \\
\text { PCT }\end{array}$ & $\uparrow$ & $\uparrow_{\text {(ADP) }}$ & $\begin{array}{l}\text { unkno } \\
\text { wn }\end{array}$ & $\begin{array}{c}\uparrow_{\text {(AIP, HCP, }} \\
\text { VP) }\end{array}$ & unknown \\
\hline $\begin{array}{l}\text { Protoporphyrinog } \\
\text { en IX }\end{array}$ & $\begin{array}{l}\text { Direct precursor of } \\
\text { protoporphyrin IX in } \\
\text { heme biosynthesis }\end{array}$ & $\uparrow_{(\mathrm{VP})}$ & $\uparrow$ & unknownt & $\begin{array}{c}\text { unknow } \\
n\end{array}$ & unknownt & $\begin{array}{l}\text { unkno } \\
\text { wn }\end{array}$ & $\uparrow_{(\mathrm{VP})}$ & unknown \\
\hline
\end{tabular}




\begin{tabular}{|c|c|c|c|c|c|c|c|c|c|}
\hline $\begin{array}{l}\text { Aminolevulinic } \\
\text { acid (ALA) }\end{array}$ & $\begin{array}{c}\text { First compound in } \\
\text { heme biosynthesis, } \\
\text { elevated in acute } \\
\text { porphyria }\end{array}$ & $\uparrow_{(A D P)}$ & unknown & $\uparrow^{\text {normal or }}(\mathrm{AIP}, \mathrm{ADP})$ & $\begin{array}{c}\text { normal/ } \\
\text { unknow } \\
n^{*}\end{array}$ & $\begin{array}{l}\text { variably } \\
\text { elevated }\end{array}$ & $\begin{array}{l}\text { unkno } \\
\text { wn }\end{array}$ & unknownt & unknown \\
\hline $\begin{array}{l}\text { Porphobilinogen } \\
\text { (PBG) }\end{array}$ & $\begin{array}{l}\text { An intermediate in } \\
\text { the heme } \\
\text { biosynthetic } \\
\text { pathway, follows } \\
\text { ALA and precedes } \\
\text { hydroxymethylbilan } \\
\text { e. Elevated in most } \\
\text { types of acute } \\
\text { porphyria. }\end{array}$ & $\begin{array}{c}\uparrow_{\text {(AIP, }} \\
\text { most cases, } \\
\text { activity of } \\
\text { PBGD } \\
\text { decreases } \\
\sim 50 \%)\end{array}$ & unknown & $\uparrow_{(\text {AIP) }}$ & $\begin{array}{c}\text { normal/ } \\
\text { unknow } \\
\text { n }\end{array}$ & $\begin{array}{c}\text { variably } \\
\text { elevated (AIP, } \\
\text { HCP, VP) } \\
\text { normal (ADP) }\end{array}$ & $\begin{array}{c}\text { unkno } \\
\text { wn }\end{array}$ & --- & unknown \\
\hline Protoporphyrin IX & $\begin{array}{c}\text { Final intermediate } \\
\text { in heme } \\
\text { biosynthesis, } \\
\text { elevated in VP }\end{array}$ & $\begin{array}{l}\text { Increased in } \\
\text { non-acute } \\
\text { EPP and } \\
\text { XLP }\end{array}$ & $\downarrow$ & $\begin{array}{l}\text { Slight } \\
\text { accumulation in } \\
\text { rat model of } \\
\text { ALA excess } \\
\text { (mimicking AIP) }\end{array}$ & $\begin{array}{c}\text { normal/ } \\
\text { unknow } \\
n^{*}\end{array}$ & unknownt & $\begin{array}{l}\text { unkno } \\
\text { wn }\end{array}$ & $\begin{array}{c}\uparrow_{(V P)} \\
\text { normal or } \\
\text { slightly } \\
\text { elevated (EPP } \\
\text { and XLP) }\end{array}$ & unknown \\
\hline $\begin{array}{l}Z n- \\
\text { Protoporphyrin IX }\end{array}$ & $\begin{array}{l}\text { Found in red blood } \\
\text { cells when heme } \\
\text { production is } \\
\text { inhibited by lead } \\
\text { and/or by lack of } \\
\text { iron }\end{array}$ & $\begin{array}{c}\uparrow_{\text {ADP }} \\
\text { Increased in } \\
\text { HEP, mildly } \\
\text { elevated or } \\
\text { normal in } \\
\text { PCT }\end{array}$ & $\uparrow$ & --- & $\begin{array}{c}\text { unknow } \\
n\end{array}$ & --- & $\begin{array}{c}\text { unkno } \\
\text { wn }\end{array}$ & --- & unknown \\
\hline Heme-CO & $\begin{array}{l}\text { Generated } \\
\text { endogenously in a } \\
\text { range of processes } \\
\text { including heme } \\
\text { catabolism. CO } \\
\text { displaces oxygen } \\
\text { and reduces } \\
\text { oxygen-carrying } \\
\text { capacity of } \mathrm{Hb} \text { in a } \\
\text { dose-dependant } \\
\text { manner. }\end{array}$ & unknownt & $\uparrow$ & --- & --- & --- & --- & --- & --- \\
\hline $\begin{array}{l}\text { Uroporphyrinoge } \\
\text { n-decarboxylase } \\
\text { (UROD) }\end{array}$ & $\begin{array}{c}\text { Catalyses fifth step } \\
\text { in heme biosynthesi } \\
\text { s by converting } \\
\text { uroporphyrinogen } \\
\text { III to } \\
\text { coproporphyrinoge } \\
\text { n III }\end{array}$ & $\begin{array}{l}\text { Decreased } \\
\text { in non- } \\
\text { acute nHEP } \\
\text { and PCT }\end{array}$ & $\downarrow$ & --- & -- & -- & --- & --- & --- \\
\hline $\begin{array}{l}\text { Protoporphyrinog } \\
\text { en- } \\
\text { oxidase (PPOX) }\end{array}$ & $\begin{array}{l}\text { Catalyses the } \\
\text { seventh step in } \\
\text { heme biosynthesis } \\
\text { by converting } \\
\text { protoporphyrinoge } \\
\text { n IX to } \\
\text { protoporphyrin IX }\end{array}$ & $\downarrow$ & $\downarrow$ & --- & --- & --- & --- & --- & --- \\
\hline $\begin{array}{l}\text { Hydroxymethylbil } \\
\text { ane/ HMBS } \\
\text { activity in RBCS }\end{array}$ & $\begin{array}{l}\text { An intermediate in } \\
\text { the heme } \\
\text { biosynthetic } \\
\text { pathway, generated } \\
\text { from porphobilinog } \\
\text { en by } \\
\text { porphobilinogen }\end{array}$ & $\begin{array}{c}\downarrow \text { in } \\
\sim 90 \% \text { cases } \\
\text { (AIP) }\end{array}$ & Normal & -- & --- & -- & --- & --- & --- \\
\hline
\end{tabular}




\begin{tabular}{|c|c|c|c|c|c|c|c|c|c|}
\hline & $\begin{array}{l}\text { deaminase. } \\
\text { Decreased in AIP. }\end{array}$ & $\begin{array}{c}\text { normal } \\
\text { (HCP, VP, } \\
\text { ADP) }\end{array}$ & & & & & & & \\
\hline $\begin{array}{l}\text { N-methyl- } \\
\text { protoporphyrin }\end{array}$ & $\begin{array}{c}\text { Inhibits } \\
\text { ferrochelatase } \\
\text { (FECH) }\end{array}$ & $\uparrow_{H P}$ & $\downarrow$ & --- & $\begin{array}{c}\text { unknow } \\
\text { n }\end{array}$ & --- & $\begin{array}{l}\text { unkno } \\
\text { wn }\end{array}$ & --- & unknown \\
\hline Total bilirubin & $\begin{array}{l}\text { Bilirubin is a } \\
\text { breakdown product } \\
\text { of heme. Total } \\
\text { bilirubin is a } \\
\text { measure of both } \\
\text { conjugated and } \\
\text { unconjugated } \\
\text { forms. }\end{array}$ & --- & --- & $\begin{array}{l}\uparrow \text { urinary } \\
\text { urobilinogen/se } \\
\text { rum total } \\
\text { bilirubin ratio } \\
\text { (AHP) }\end{array}$ & $\downarrow$ & $\begin{array}{l}\text { Hyperbilirubine } \\
\text { mia is typical of } \\
\text { porphyria }\end{array}$ & $\begin{array}{l}\text { unkno } \\
\text { wn }\end{array}$ & $\begin{array}{l}\text { Hyperbilirubine } \\
\text { mia is typical or } \\
\text { porphyria }\end{array}$ & unknown \\
\hline $\begin{array}{l}\text { Ratio } \\
\text { Bilirubin/Fe- } \\
\text { Heme }\end{array}$ & $\begin{array}{l}\text { Bilirubin is a } \\
\text { breakdown product } \\
\text { of heme }\end{array}$ & --- & --- & unknownt & $\uparrow$ & --- & --- & --- & --- \\
\hline $\begin{array}{l}\text { Heme oxygenase } \\
\text { I (HMOX-1) }\end{array}$ & $\begin{array}{l}\text { Degrades heme to } \\
\text { carbon monoxide } \\
\text { (CO), iron, and } \\
\text { biliverdin }\end{array}$ & $\begin{array}{l}\uparrow \text { in rat } \\
\text { models of } \\
\text { induced } \\
\text { hepatic } \\
\text { porphyria }\end{array}$ & $\uparrow$ & --- & --- & --- & --- & --- & --- \\
\hline $\begin{array}{l}\text { Ferrochelatase } \\
\text { (FECH) }\end{array}$ & $\begin{array}{l}\text { Catalyses the } \\
\text { formation of heme } \\
\text { by transferring iron } \\
\text { to protoporphyrin- } \\
\text { IX }\end{array}$ & $\begin{array}{l}\downarrow \text { (VP } \\
\text { and EP) }\end{array}$ & $\uparrow$ & --- & --- & --- & --- & --- & --- \\
\hline
\end{tabular}


Figure 3

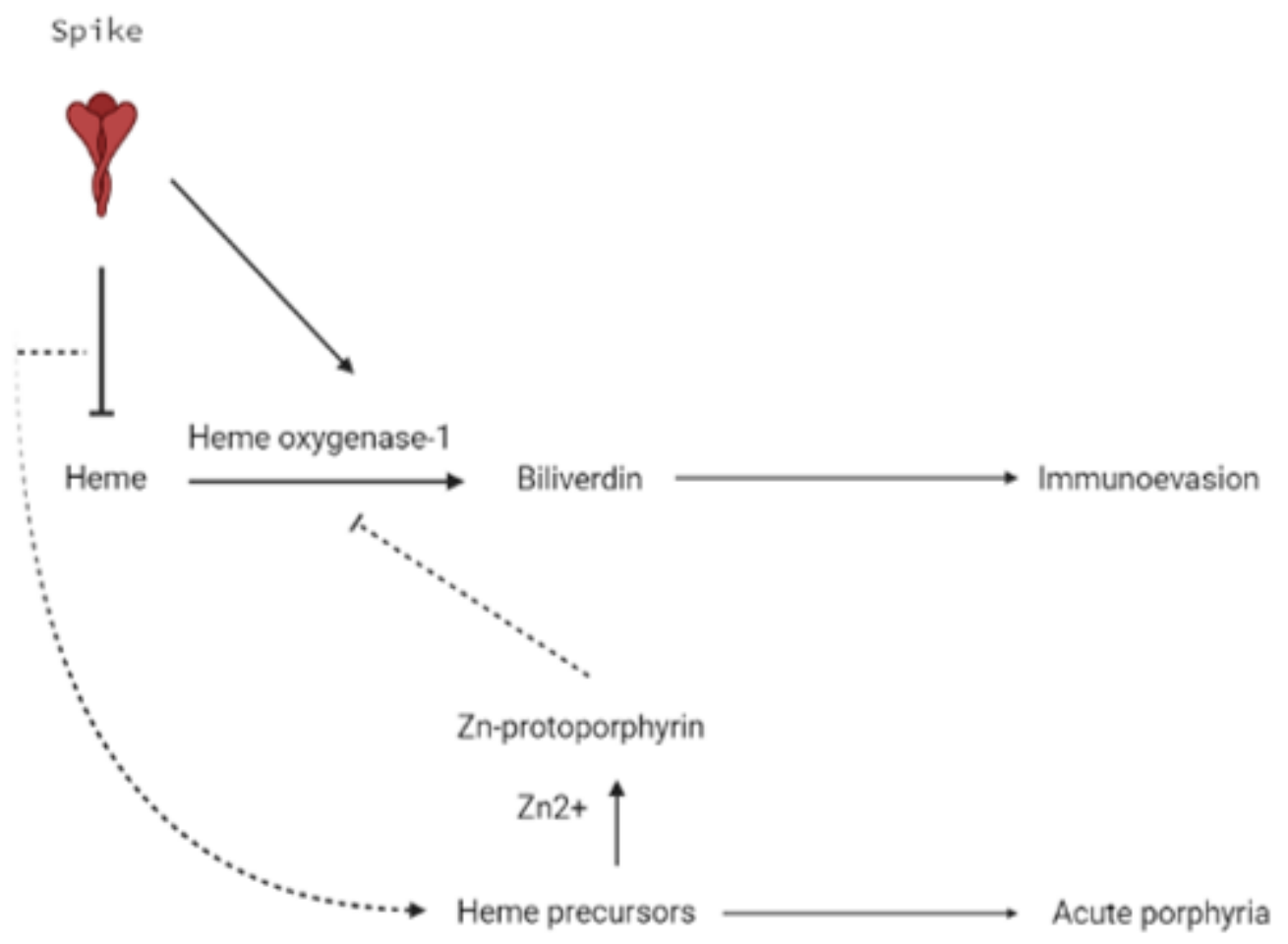


Figure 4

\section{FImpre re}

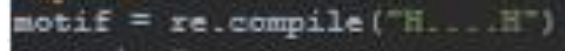

protein $=$

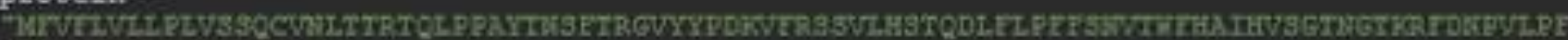

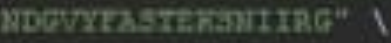

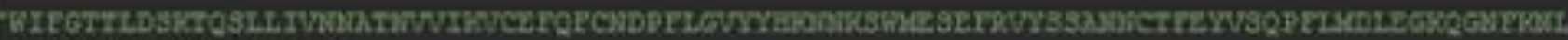

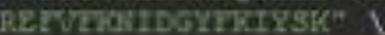

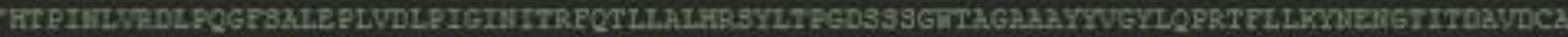

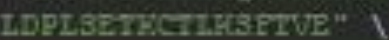

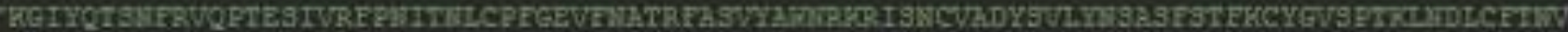

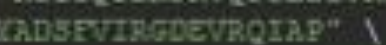

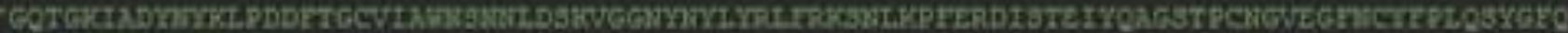

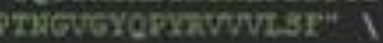

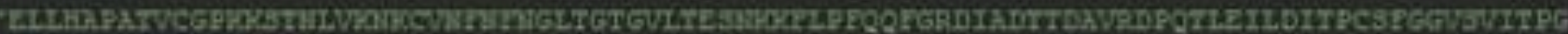

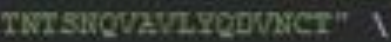

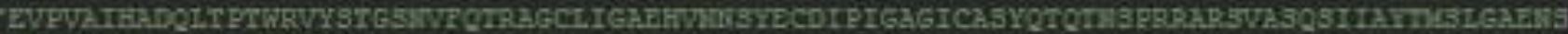

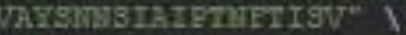

Texth

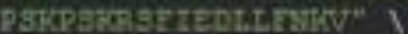

4tha

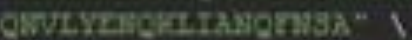

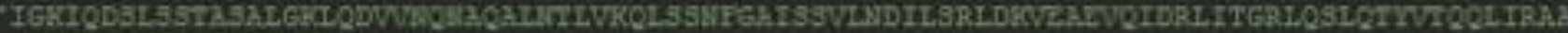

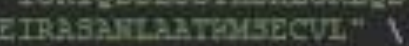

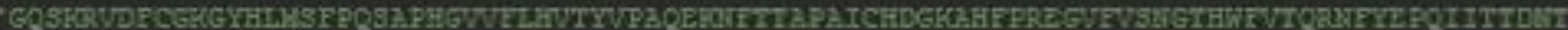

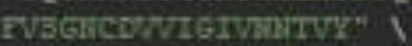

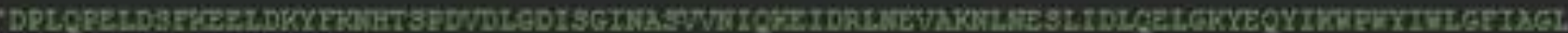

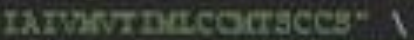

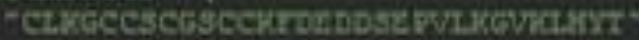

$\mathrm{a}=$ motif-ecareh (protein)

iff 료:

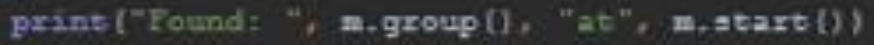

ele :

print (rot found" $)$

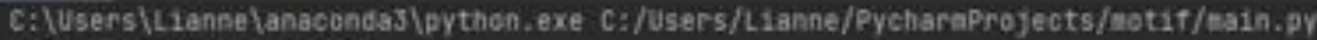

Found? HOGKAH at 1062

Process fintshed with exit code 8 


\begin{tabular}{|c|c|c|c|c|}
\hline Sub-sequence & Motif & Position & Region & Motif Source \\
\hline $\begin{array}{c}\text { HDGKA } \\
\mathrm{H}\end{array}$ & HXXXXH & 1082 & S2 & NCBI accession AHE16524.1 \\
\hline $\mathrm{CP}$ & Cys-Pro & 335 & $\begin{array}{c}\text { RB } \\
D\end{array}$ & Kühl et al 2013 (126) \\
\hline HY & His-Tyr & 1270 & S2 & Syllwasschy et al 2020 (125) \\
\hline $\mathrm{YH}$ & Tyr-His & 144 & $\begin{array}{c}\text { NT } \\
\text { D }\end{array}$ & Syllwasschy et al 2020 (125) \\
\hline YY & Tyr-Tyr & 36 & $\begin{array}{c}\text { NT } \\
\text { D }\end{array}$ & Syllwasschy et al 2020 (125) \\
\hline YYH & $\mathrm{YXH}$ & 143 & $\begin{array}{c}\text { NT } \\
\text { D }\end{array}$ & Syllwasschy et al 2020 (125) \\
\hline YNY & YXY & 420 & $\begin{array}{c}\text { RB } \\
D\end{array}$ & Syllwasschy et al 2020 (125) \\
\hline HAIH & $\mathrm{HXXH}$ & 65 & $\begin{array}{c}\text { NT } \\
\text { D }\end{array}$ & Syllwasschy et al 2020 (125) \\
\hline HRSY & HXXY & 244 & $\begin{array}{c}\text { NT } \\
\text { D }\end{array}$ & Syllwasschy et al 2020 (125) \\
\hline YSKH & YXXH & 203 & $\begin{array}{c}\text { NT } \\
\text { D }\end{array}$ & Syllwasschy et al 2020 (125) \\
\hline YVGY & YXXY & 265 & $\begin{array}{c}\text { NT } \\
\text { D }\end{array}$ & Syllwasschy et al 2020 (125) \\
\hline YFKNH & $\begin{array}{c}\text { YXXX } \\
H\end{array}$ & 1154 & S2 & Syllwasschy et al 2020 (125) \\
\hline YFKIY & YXXXY & 199 & $\begin{array}{c}\text { NT } \\
\text { D }\end{array}$ & Syllwasschy et al 2020 (125) \\
\hline
\end{tabular}


Figure 5

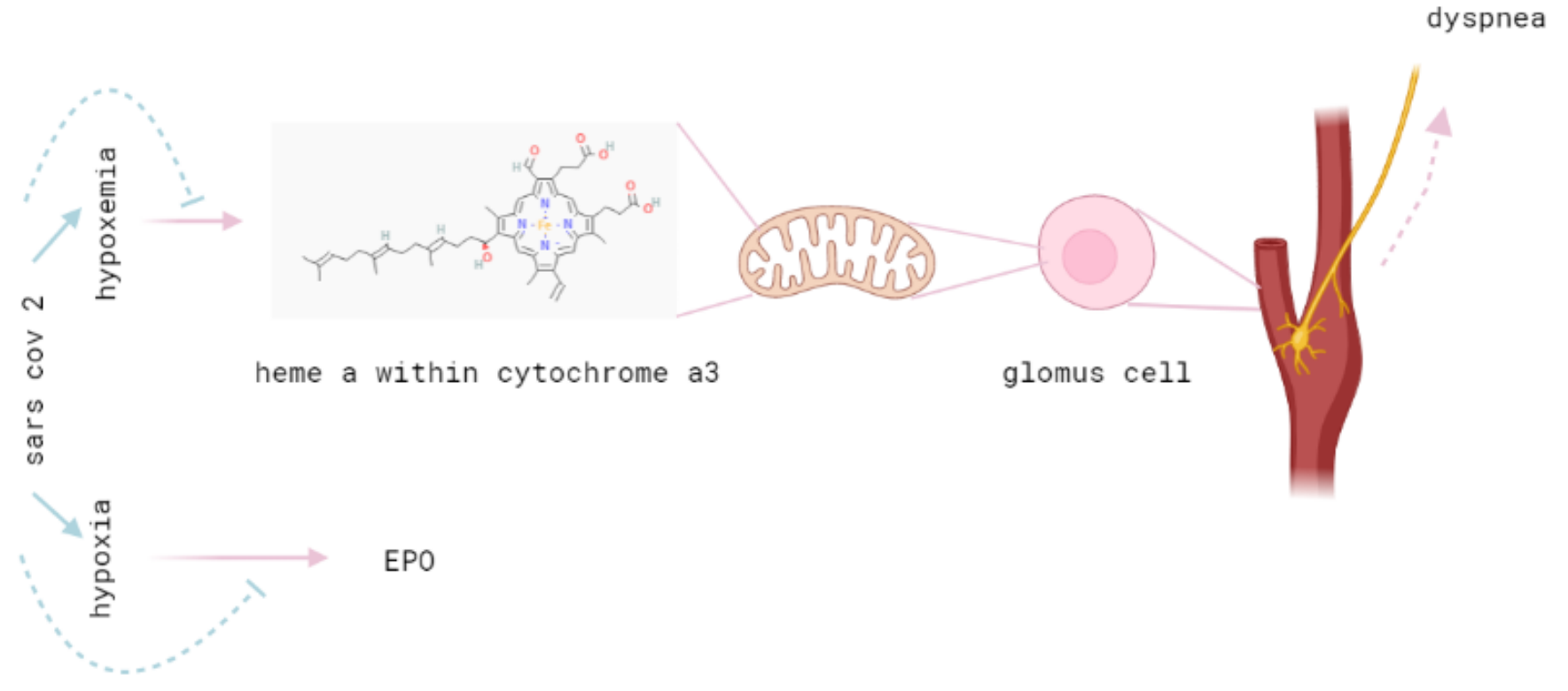


Figure 6
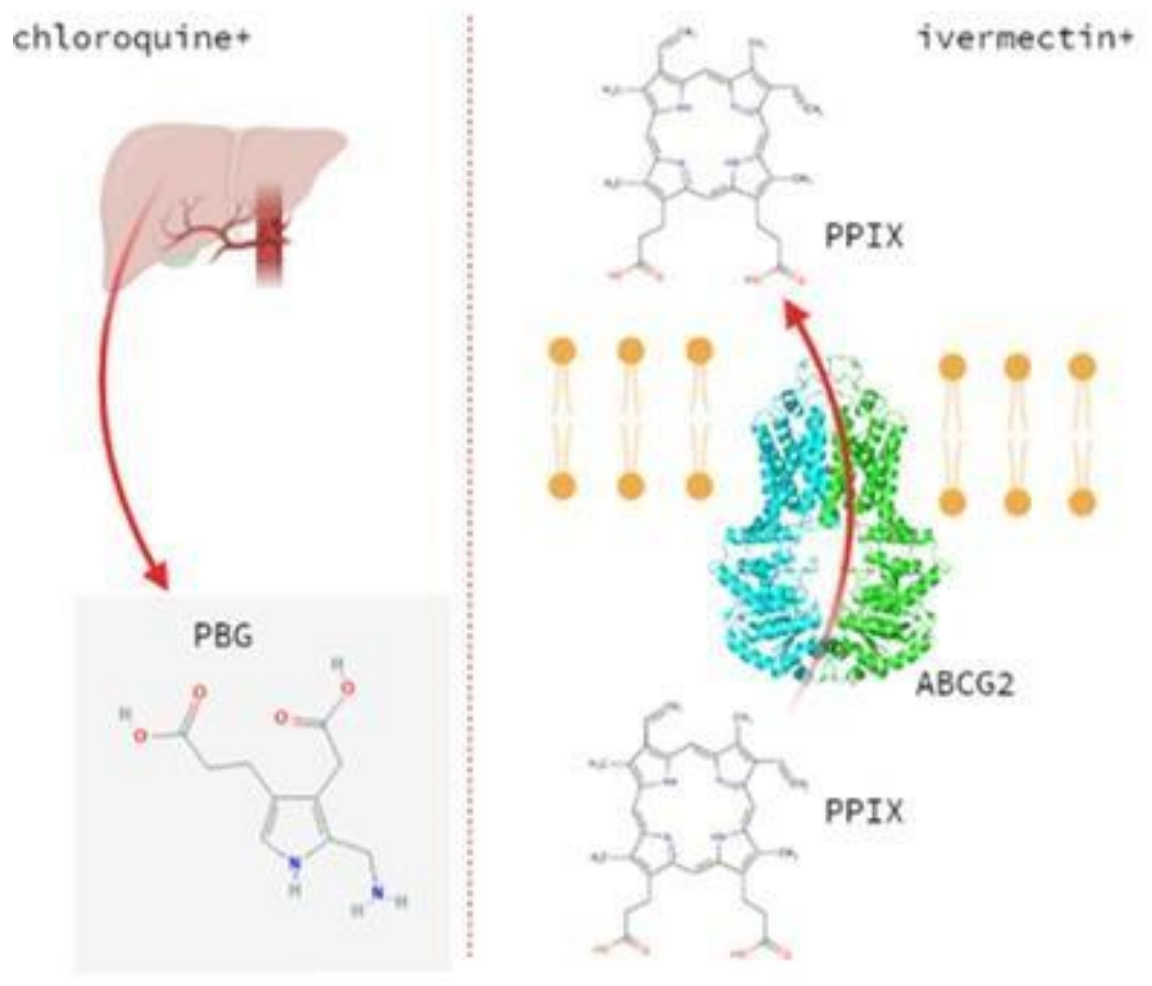